\title{
Greenhouse gases from membrane bioreactors: Mathematical modelling, sensitivity and uncertainty analysis
}

\author{
Giorgio Mannina ${ }^{a}$, Alida Cosenza ${ }^{a, *}$, George A. Ekama ${ }^{b}$ \\ a Dipartimento di Ingegneria Civile, Ambientale, Aerospaziale, dei Materiali, Università di Palermo, Viale delle Scienze, Ed.8, 90100 Palermo, Italy \\ ${ }^{\mathrm{b}}$ Water Research Group, Department of Civil Engineering, University of Cape Town, Rondebosch, 7700 Cape, South Africa
}

\section{H I G H L I G H T S}

- A new greenhouse gas emissions model from membrane bioreactors (MBRs) is presented.

- The salinity influence during biomass growth has been considered in the model.

- $50 \%$ of model factors selected as important by means sensitivity analysis.

- Salinity has influenced $\mathrm{N}_{2} \mathrm{O}$ emissions during nitrification.

- Good model predictions obtained with respect to the measured data.

\section{A R T I C L E I N F O}

\section{Article history:}

Received 1 March 2017

Received in revised form 1 May 2017

Accepted 3 May 2017

Available online 6 May 2017

\section{Keywords:}

Uncertainty

Greenhouse gases

Wastewater

Membrane

Modelling

\section{G R A P H I C A L A B S T R A C T}

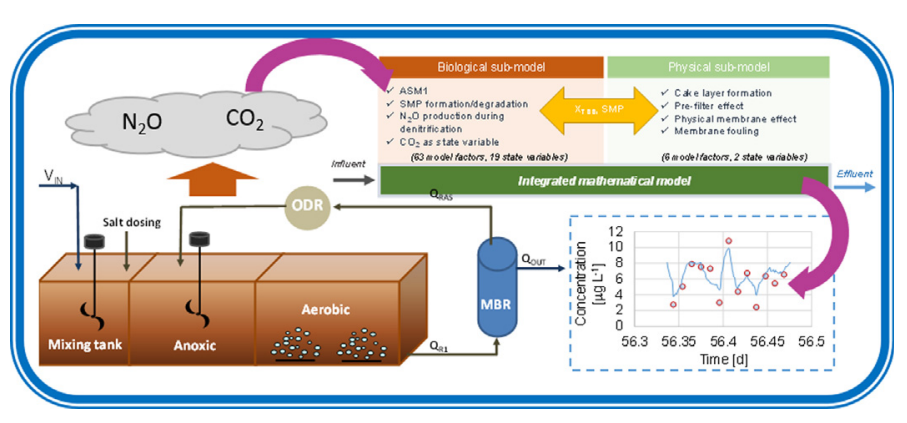

\begin{abstract}
A B S T R A C T
In this study a new mathematical model to quantify greenhouse gas emissions (namely, carbon dioxide and nitrous oxide) from membrane bioreactors (MBRs) is presented. The model has been adopted to predict the key processes of a pilot plant with pre-denitrification MBR scheme, filled with domestic and saline wastewater. The model was calibrated by adopting an advanced protocol based on an extensive dataset. In terms of nitrous oxide, the results show that an important role is played by the half saturation coefficients related to nitrogen removal processes and the model factors affecting the oxygen transfer rate in the aerobic and MBR tanks. Uncertainty analysis showed that for the gaseous model outputs $88-93 \%$ of the measured data lays inside the confidence bands showing an accurate model prediction.
\end{abstract}

(c) 2017 Elsevier Ltd. All rights reserved.

\section{Introduction}

Wastewater treatment plants (WWTPs) can emit greenhouse gases (GHGs) (such as carbon dioxide, $\mathrm{CO}_{2}$, nitrous oxide, $\mathrm{N}_{2} \mathrm{O}$ and methane, $\mathrm{CH}_{4}$ ). Among the potential GHGs produced from a WWTPs, $\mathrm{N}_{2} \mathrm{O}$ is the most environmentally hazardous due to its strong global warming potential (GWP) (298 higher that $\mathrm{CO}_{2}$ )

\footnotetext{
* Corresponding author.

E-mail address: alida.cosenza@unipa.it (A. Cosenza).
}

and its capacity to deplete the stratospheric ozone layer (IPCC, 2013). An accurate quantification and mitigation of GHG emissions from WWTP is imperative for improved environmental protection. With this respect, mathematical models can be useful and powerful tools.

In the past, several efforts have been performed for establishing the best tool to predict/quantify GHG (Ni and Yuan, 2015; Mannina et al., 2016a, 2016b; Hiatt and Grady, 2008; Ni et al., 2013; Peng et al., 2015; Spérandio et al., 2016; Pocquet et al., 2016). These efforts are based on the modifications of the Activated Sludge 
Models (ASMs) (Henze et al., 2000) to include GHG formation/ emission processes (Ni and Yuan, 2015; Mannina et al., 2016a, 2016b).

Corominas and co-workers demonstrated that mechanistic process-based dynamic models represent the best way to predict GHG emissions (Corominas et al., 2012). Ni et al. (2013) compared four mathematical models describing the $\mathrm{N}_{2} \mathrm{O}$ production by means of ammonia oxidising bacteria ( $\mathrm{AOB}$ ) as the final product of nitrifier denitrification or as a product of incomplete oxidation of hydroxylamine $\left(\mathrm{NH}_{2} \mathrm{OH}\right)$. They found that none of the tested models was able to fully simulate the measured data. Very recently, Spérandio et al. (2016) compared the results of five ASM family-like models describing $\mathrm{N}_{2} \mathrm{O}$ production by AOB. Similarly to previous studies (i.e., Ni et al., 2013), Spérandio et al. (2016) found that, despite at least one of the investigated models being able to reproduce the measured data, none of the tested models were able to simulate measured data using the same parameter data set.

A new model which combines two $\mathrm{N}_{2} \mathrm{O}$ emission pathways due to AOB was recently proposed and calibrated (Pocquet et al., 2016). This model showed good correlation between measured and modelled data in long-term simulation periods.

The aforementioned studies mainly refer to conventional activated systems with solid-liquid separation with secondary settling tanks (CASs). However, there is limited research on modelling GHG emissions from advanced wastewater treatment systems such as membrane bioreactors (MBR). MBRs have some specific peculiarities (i.e., membrane fouling, biomass selection; intensive aeration for membrane fouling mitigation), which can influence GHG emissions and hamper a straightforward transferability of CAS models to MBR systems. For example, the Soluble Microbial Product (SMP) formation/degradation processes and the role played by membrane aeration on GHG stripping are generally not considered in CAS models but can be of paramount importance for MBR system modelling.

A first attempt to GHG modelling from MBRs was recently presented (Mannina and Cosenza, 2015). In particular, Mannina and Cosenza (2015) developed a model able to estimate $\mathrm{CO}_{2}$ and $\mathrm{N}_{2} \mathrm{O}$ emissions from an MBR system with University Cape Town (UCT) - MBR scheme. An extensive sensitivity analysis was presented aimed at identifying the key influencing factors. Despite the promising performance of the model, it was not calibrated using real MBR system data.

Recent studies on the estimation of the uncertainty in GHG modelling confirmed the relevant role played by such an analysis (Sweetapple et al., 2013). Indeed, the assessment of the uncertainty may improve the calibration process. Sensitivity and uncertainty analyses help the modeller identify the key constants affecting model outputs (Sweetapple et al., 2013). However, despite the usefulness of uncertainty analysis, only few such studies have been performed (Mannina and Cosenza, 2015; Sweetapple et al., 2013). Sensitivity and uncertainty analysis may have a relevant role in MBR modelling, because, as recently demonstrated by Mannina and Cosenza (2015), model constants related to the physical processes of the membrane solid-liquid separation can also affect GHG production.

In this paper a new mathematical model for GHG emission evaluation from MBRs is presented. The model takes into account the main physical and biological processes: solid/liquid separation, membrane fouling and SMP formation/degradation. The mathematical model has been adopted to predict the key biological processes of a sequential batch (SB) MBR pilot plant fed with real saline wastewater. A long-term data base (for dissolved and gaseous $\mathrm{N}_{2} \mathrm{O}$ ), acquired during an extensive measurement campaign, was adopted for the model calibration. Model uncertainty was quantified to better assess model features.

\section{Material and methods}

\subsection{The mathematical model}

The mathematical model proposed in this work couples the ASM1 model (Henze et al., 2000) and the $\mathrm{N}_{2} \mathrm{O}$ modelling approach of Hiatt and Grady (2008). The mathematical model consists of two sub-models (Fig. 1): a biological sub-model and a physical submodel. All biological model (stoichiometric, kinetic and fractionation) and physical model factors are reported in Table A.1.

The biological sub-model couples the ASM1, the SMP formation/degradation processes, the $\mathrm{N}_{2} \mathrm{O}$ formation during the denitrification and the $\mathrm{CO}_{2}$ production during the biological metabolism (Fig. 1). The biological sub-model involves: 16 biological processes (aerobic and anoxic); 19 state variables, which include dissolved $\mathrm{N}_{2} \mathrm{O}$ and $\mathrm{CO}_{2}\left(\mathrm{~S}_{\mathrm{N} 2 \mathrm{O}}\right.$ and $\mathrm{S}_{\mathrm{CO} 2}$, respectively) and 63 model factors. In Tables A.2 and A.3 of the Appendix the Gujer Matrix and the process rate equations of the biological model are reported, respectively.

In order to consider the SMP formation/degradation processes two new state variables have been included: (i) soluble utilization-associated products $\left(\mathrm{S}_{\mathrm{UAP}}\right)$ and (ii) soluble biomassassociated products $\left(\mathrm{S}_{\mathrm{BAP}}\right)$. Furthermore, the aerobic and anoxic hydrolysis processes of $\mathrm{S}_{\mathrm{UAP}}$ and $\mathrm{S}_{\mathrm{BAP}}$ have been added in the ASM1 (see processes 1-4 of Table A.3). Thus, four new model parameters have been introduced in the model according to Jiang et al. (2008): the hydrolysis rate coefficient for $S_{\text {BAP }}$ and $S_{U A P}\left(k_{h}\right.$, BAP and $k_{h, U A P}$, respectively) in the kinetics rate expressions (Table A.3) and the production of $\mathrm{S}_{\mathrm{UAP}}$ and $\mathrm{S}_{\mathrm{BAP}}$ in the biomass growth and endogenous decay process stoichiometry via the ( $f_{B A P}$ and $\mathrm{f}_{\mathrm{UAP}}$ ) coefficients. The $\mathrm{S}_{\mathrm{BAP}}$ and $\mathrm{S}_{\mathrm{UAP}}$ reduction follows a first order kinetics. For example, the rate of the anoxic hydrolysis of $S_{B A P}$ is shown in Eq. (1).

$\mathrm{k}_{\mathrm{h}, \mathrm{BAP}} \cdot \eta_{\mathrm{NO3,HYD}} \cdot\left[\frac{\mathrm{K}_{\mathrm{O} 2, \mathrm{HYD}}}{\mathrm{K}_{\mathrm{O} 2, \mathrm{HYD}}+\mathrm{S}_{\mathrm{O} 2}}\right] \cdot\left[\frac{\mathrm{S}_{\mathrm{NO} 3}}{\mathrm{~K}_{\mathrm{NO} 3, \mathrm{HYD}}+\mathrm{S}_{\mathrm{NO} O}}\right] \cdot \mathrm{S}_{\mathrm{BAP}} \cdot \mathrm{X}_{\mathrm{H}}$

Moreover, the aerobic and anoxic kinetic hydrolysis processes of $\mathrm{X}_{\mathrm{s}}$ have been modified in the model (see processes 5-6 of Table A.3) to include the production of unbiodegradable soluble organics $\left(\mathrm{S}_{\mathrm{I}}\right)$. The model has been expanded to describe the nitrification and denitrification processes according in two step (see processes 13-14 of Table A.3) and four step (see processes 8-11 of Table A.3) processes respectively as described by Hiatt and Grady (2008). So the autotrophic biomass is modelled with an ammonia-oxidising biomass $\left(\mathrm{X}_{\mathrm{AOB}}\right)$ and a nitrite oxidising biomass $\left(\mathrm{X}_{\mathrm{NOB}}\right)$. The denitrification is modelled with a single ordinary heterotrophic organism (OHO) biomass $\left(\mathrm{X}_{\mathrm{OHO}}\right)$ utilizing soluble biodegradable organics $\left(S_{S}\right)$ in four sequential steps of electron transfer in the electron acceptor from nitrate to nitrite, to nitric oxide (NO) to nitrous oxide $\left(\mathrm{N}_{2} \mathrm{O}\right)$ to nitrogen gas $\left(\mathrm{N}_{2}\right)$. Specifically, each step has its own $\eta$ specific growth rate reduction factor for anoxic denitrification relative to the aerobic $\mathrm{OHO}$ maximum specific growth rate $\left(\mu_{\mathrm{OHO} \text { or }} \mu_{\mathrm{H}}\right)$. Specifically, $\mathrm{S}_{\mathrm{NO} 3}$ to $\mathrm{S}_{\mathrm{NO} 2}\left(\eta_{\mathrm{g} 2}\right), \mathrm{S}_{\mathrm{NO} 2}$ to $S_{\mathrm{NO}}\left(\eta_{\mathrm{g} 3}\right), S_{\mathrm{NO}}$ to $S_{\mathrm{N} 2 \mathrm{O}}\left(\eta_{\mathrm{g} 4}\right)$ and $S_{\mathrm{N} 2 \mathrm{O}}$ to $S_{\mathrm{N} 2}\left(\eta_{\mathrm{g} 5}\right)$ have been introduced. This is equivalent to giving the $\mathrm{OHO}$ a different and independent maximum specific growth rate for each of the four steps in the denitrification from nitrate to $\mathrm{N}_{2}$ all utilizing soluble biodegradable organics $\left(S_{S}\right)$ as electron donor. For example, the kinetic rate related to the anoxic growth of heterotrophic biomass on soluble biodegradable organics $\left(\mathrm{S}_{\mathrm{S}}\right)$ reducing $\mathrm{S}_{\mathrm{NO}}$ to $\mathrm{S}_{\mathrm{N} 2 \mathrm{O}}$ (Bioprocess 10 in Table A.3) is reported in Eq. (1). In Eq. (1) both the switching functions related to the alkalinity $\left(\frac{S_{A L K}}{K_{A L K}+S_{A L K}}\right)$ and the ammonia $\left(\frac{S_{N H 4}}{K_{N H 4, H}+S_{N H 4}}\right)$ have been introduced according to the cor- 


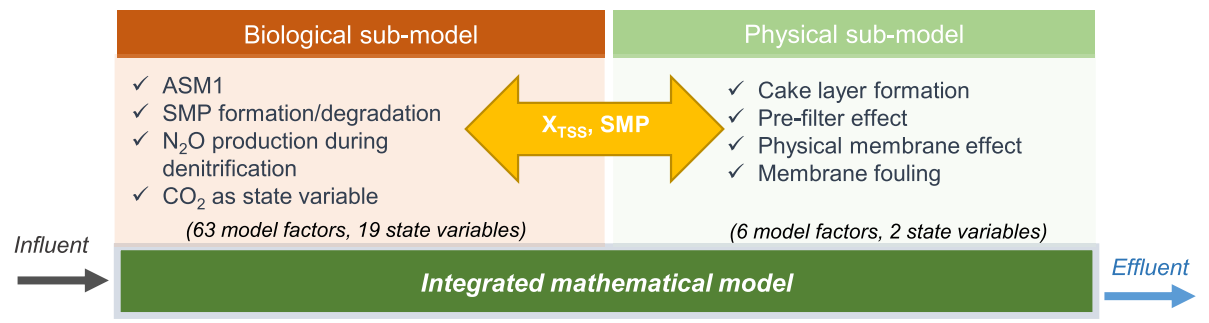

Fig. 1. Conceptual structure of the mathematical model; SMP = soluble microbial product; $\mathrm{X}_{\mathrm{TSS}}=$ total suspended solids.

rections of the ASM1 as proposed by Hauduc et al. (2011). Also added are two NO terms, one inhibition term, which decreases the rate when the NO concentration gets high relative to the $\mathrm{K}_{\mathrm{I} 4 \mathrm{NO}}$ inhibition concentration and one switching term, which decreases the specific growth rate when the NO concentration gets low relative to $\mathrm{K}_{\mathrm{I} \text { INo. }}$. The kinetic rate equations of the 16 bioprocesses in the biological sub-model are shown in Table A.3. The internal consistence of the Gujer matrix was checked and found to conform to mass balance continuity.

$$
\begin{gathered}
\mu_{H} \cdot \eta_{g 4} \cdot\left[\frac{K_{O 2, H}}{K_{O 2, H}+S_{O 2}}\right] \cdot\left[\frac{S_{N O}}{K_{N O}+S_{N O}+\frac{S_{N O}^{2}}{K_{14 N O}}}\right] \cdot\left[\frac{S_{S}}{K_{S}+S_{S}}\right] \\
\cdot\left[\frac{S_{N H 4}}{K_{N H 4, H}+S_{N H 4}}\right] \cdot\left[\frac{S_{A L K}}{K_{A L K}+S_{A L K}}\right] \cdot\left[\frac{K_{I 3 N O}}{K_{I 3 N O}+S_{N O}}\right] \cdot X_{H}
\end{gathered}
$$

The model includes the stripping processes for $\mathrm{N}_{2} \mathrm{O}$ and $\mathrm{CO}_{2}$ gases to evaluate $\mathrm{N}_{2} \mathrm{O}$ and $\mathrm{CO}_{2}$ emission, namely $\mathrm{S}_{\mathrm{GHG}, \mathrm{N} 2 \mathrm{O}}$ and $\mathrm{S}_{\mathrm{GHG}, \mathrm{CO} 2}$ respectively. The stripping processes for both $\mathrm{N}_{2} \mathrm{O}$ and $\mathrm{CO}_{2}$ is modelled including in the mass balance the term of Eq. (3) (Sabba et al., 2016).

$-K_{L} a \cdot\left(\mathrm{S}_{\mathrm{GHG}, \mathrm{N} 2 \mathrm{O}} \cdot \mathrm{H}_{\mathrm{N} 2 \mathrm{O}}-\mathrm{S}_{\mathrm{N} 2 \mathrm{O}}\right)$

where $\mathrm{K}_{\mathrm{L}} \mathrm{a}\left[\mathrm{h}^{-1}\right]$ is the gas-liquid mass transfer coefficient, $\mathrm{S}_{\mathrm{GHG}, \mathrm{N} 2 \mathrm{O}}$ [ $\mathrm{mol} \mathrm{m}^{-3}$ ] is the gaseous $\mathrm{N}_{2} \mathrm{O}$ concentration in the off-gas, $\mathrm{H}_{\mathrm{N} 2 \mathrm{O}}$ [mol mol${ }^{-1}$ ] is the Henry gas-liquid coefficient of $\mathrm{N}_{2} \mathrm{O}$ at $25^{\circ} \mathrm{C}$ and $\mathrm{S}_{\mathrm{N} 2 \mathrm{O}}\left[\mathrm{mol} \mathrm{m}^{-3}\right]$ is the dissolved $\mathrm{N}_{2} \mathrm{O}$ concentration in the mixed liquor. The stripping process for $\mathrm{CO}_{2}$ has been similarly described. For $\mathrm{N}_{2} \mathrm{O}$ and $\mathrm{CO}_{2}$ the $\mathrm{K}_{\mathrm{L}} \mathrm{a}$ was estimated according to Mampaey et al. (2015).

The biological model includes the influence of the influent salinity both for the autotrophic and heterotrophic biomass (Park and Marchland, 2006). More precisely, the maximum growth rate of both autotrophic and heterotrophic biomass is modelled considering a reduction coefficient (i.e., $I_{s}$ coefficient), assessed as:

$I_{S}=\frac{I_{S}^{*} \cdot(\% \mathrm{NaCl})}{0.01+\% \mathrm{NaCl}}$

where $\mathrm{I}_{\mathrm{s}}^{*}$ is the inhibition factor evaluated and $\% \mathrm{NaCl}$ is the percentage of salinity expressed as $\mathrm{NaCl}$ content. Eq. (4) is valid in the range of $0-4 \% \mathrm{NaCl}$ as indicated by Park and Marchland (2006). Therefore, under $0 \% \mathrm{NaCl}$ condition $\mathrm{I}_{\mathrm{s}}$ is equal to zero. Conversely, $\mathrm{I}_{\mathrm{s}}$ has a constant value at higher salinity levels (each constant value for each influent $\% \mathrm{NaCl}$ ). In this work two inhibition factors have been considered one for heterotrophic and another for autotrophic biomass $\left(\mathrm{I}_{\mathrm{S}, \mathrm{H}}\right.$ and $\mathrm{I}_{\mathrm{S}, \mathrm{A}}$, respectively).

The physical sub-model takes into account the main physical processes of an MBR which interact with the biological submodel (Mannina et al., 2011a) (Fig. 1). The key algorithms of the physical sub-model are reported in Table A.4.

The physical sub-model involves 6 model factors. Specifically, the following six processes are taken into account: (i) solids deposition and detachment on/from membrane surface during the filtration and backwashing, respectively (cake layer forma- tion); (ii) carbon removal due to cake layer which acts as a filter; (iii) carbon removal due to physical membrane; (iv) solute deposition within membrane pore (pore fouling); (v) pore blocking and (vi) influence of SMP on pore fouling. The same sectional method of Li and Wang (2006) was used to model membrane; according to this method membrane surface is divided into $\mathrm{N}$ areal fractions. In order to take into account the influence of the distance of the aeration system on the membrane fouling, a different value of shear intensity of the fluid turbulence $(G)$ is considered on the basis of this distance. Both reversible and irreversible fouling mechanisms are considered. Reversible fouling is modelled as a continuous cake layer formation/removal during filtration/backwashing phases. Irreversible fouling modelling is performed by considering two mechanisms: pore fouling, due to the solute deposition within the membrane pores, and stable cake fouling due to the particle deposition on membrane surface that cannot be removed by means of the backwashing. The physical and biological sub-models interact by means of: TSS, which influence the cake layer; COD which is partially retained within the cake layer; SMP, which influence membrane fouling.

For a detailed description of the physical sub-model reader is referred to the literature (Mannina and Cosenza, 2013).

\subsection{The case study}

The SB-MBR pilot plant taken into account has a predenitrification scheme (Fig. 2).

The solid/liquid separation occurred by means of an hollow fiber ultrafiltration membrane module in Polyvinylidene fluoride (PVDF) (Zenon Zeeweed, ZW10) submerged into an aerated tank (MBR). The hollow fiber membrane has a width specific area equal to $0.98 \mathrm{~m}^{2}$ and a nominal porosity of $0.04 \mu \mathrm{m}$. In order to ensure anoxic conditions, inside the anoxic reactor, an oxygen depletion reactor (ODR) was inserted within the recycle line between the anoxic reactor and MBR. Each reactor (aerobic, anoxic and MBR) was covered in order to ensure the gas accumulation and the subsequent sampling.

The real domestic wastewater was stored inside a feeding tank and discontinuously fed into the pilot plant by using the fill-drawbatch approach. The pilot plant filling occurred according to 8 cycles per day, each of $3 \mathrm{~h}$ duration. During each cycle $40 \mathrm{~L}$ of wastewater $\left(\mathrm{V}_{\mathrm{IN}}\right)$ previously mixed with salt were fed and treated. Each cycle was divided into two phases: i. biological reaction $(1 \mathrm{~h})$; ii. filtration $(2 \mathrm{~h})$. During the biological reaction phase no permeate extraction occurred, therefore the permeate flow rate ( $\mathrm{Q}_{\text {out }}$ ) was equal to zero. Conversely, during the filtration phase $Q_{\text {out }}$ was set to $20 \mathrm{~L} \mathrm{~h}^{-1}$ and the permeate flux was equal to $21 \mathrm{~L} \mathrm{~m}^{2} \mathrm{~h}^{-1}$. During the filtration phase, the membrane was backwashed every $9 \mathrm{~min}$ for a period of $1 \mathrm{~min}$; the backwashing has been performed by reintroducing a fraction of the permeate back into the internal lumen of the hollow fiber.

Mixed liquor was continuously recycled from the aerobic to $\operatorname{MRR}\left(Q_{R 1}\right.$ equal to $\left.80 \mathrm{~L} \mathrm{~h}^{-1}\right)$ and from the MBR to the anoxic reac- 


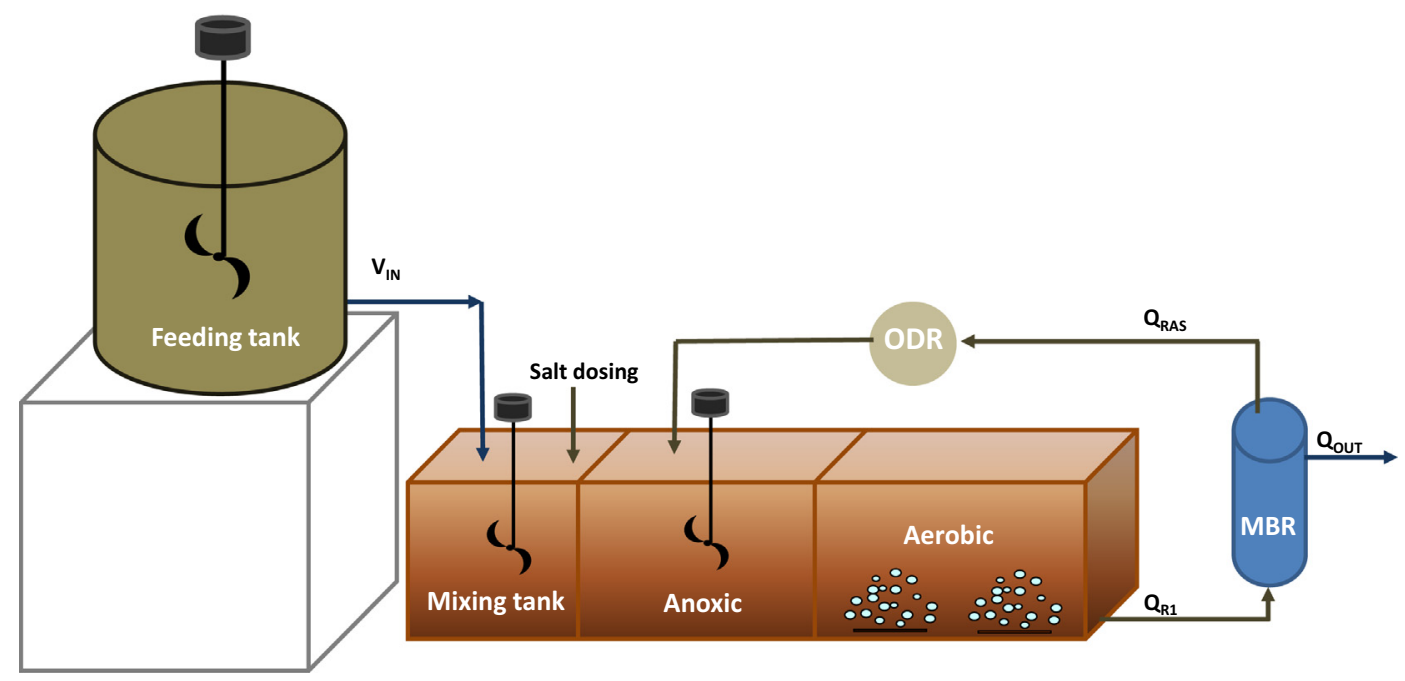

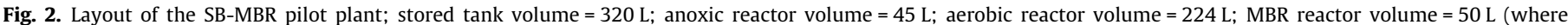

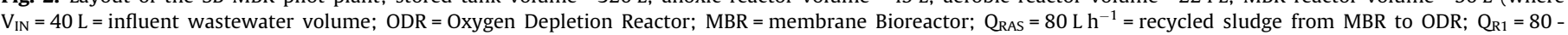
$\mathrm{L} \mathrm{h}^{-1}$ = sludge feeding from aerobic tank to MBR; $\mathrm{Q}_{\mathrm{Out}}=20 \mathrm{~L} \mathrm{~h}^{-1}$ (only during the MBR filtration phase = effluent flow rate).

tor $\left(\mathrm{Q}_{\mathrm{RAS}}\right.$, equal to $80 \mathrm{~L} \mathrm{~h}^{-1}$ during the biological reaction phase and $60 \mathrm{~L} \mathrm{~h}^{-1}$ during the filtration phase).

The pilot plant was monitored for three months. The 84 day experimental campaign was divided into six phases each characterized by a specific salt concentration from 0 up to $10 \mathrm{~g} \mathrm{NaCl} \mathrm{L}^{-1}$. The $\mathrm{NaCl}$ concentration in the influent was increased at steps of $2 \mathrm{~g}$ $\mathrm{NaCl} \mathrm{L}{ }^{-1}$ on a weekly basis. The last Phase VI had a duration of 26 days. No sludge was wasted from the system during the investigation making the sludge age indeterminate. During the experimental campaign liquid samples withdrawn (every $15 \mathrm{~min}$ and $60 \mathrm{~min}$ for the gas and liquid samples, respectively) from the aerobic and anoxic tank were analyzed in order to evaluate gaseous and dissolved $\mathrm{N}_{2} \mathrm{O}$. With this regards a Gas Chromatograph (Thermo Scientific ${ }^{\mathrm{TM}}$ TRACE GC) equipped with an Electron Capture Detector was used. Both aerobic and anoxic tanks were covered and sealed in order to allow gas samples. Furthermore, the $\mathrm{N}_{2} \mathrm{O}$ $\mathrm{N}$ fluxes $\left(\mathrm{gN}_{2} \mathrm{O}-\mathrm{N} \mathrm{m}^{-2} \mathrm{~h}^{-1}\right)$ from aerobic and anoxic tanks were quantified by measuring the gas flow rates, $\mathrm{Q}_{\mathrm{GAS}}\left(\mathrm{L} \mathrm{min}^{-1}\right)$. During plant operations, the influent wastewater, the mixed liquor inside the anoxic and aerobic tank and the effluent permeate were sampled and analyzed for total and volatile suspended solids (TSS and VSS), total chemical oxygen demand $\left(\mathrm{COD}_{\mathrm{TOT}}\right)$, supernatant COD $\left(\mathrm{COD}_{\text {sol }}\right)$, ammonium nitrogen $\left(\mathrm{NH}_{4}-\mathrm{N}\right)$, nitrite nitrogen $\left(\mathrm{NO}_{2}-\mathrm{N}\right)$, nitrate nitrogen $\left(\mathrm{NO}_{3}-\mathrm{N}\right)$, total dissolved nitrogen (TN), ortho-phosphate $\left(\mathrm{PO}_{4}-\mathrm{P}\right)$, total dissolved organic carbon (TOC) and inorganic carbon (IC). Further, transmembrane pressure (TMP) [bar] data were measured by means of an analogue data logger every $1 \mathrm{~min}$. Moreover, instantaneous permeate flow rate (Qout,i $)$ was measured every day in order to evaluate the total membrane resistance $\mathrm{R}_{\mathrm{T}}$ [ $\mathrm{m}^{-1}$ ] according to Eq. (5). Further details on the experimental campaign can be drawn from previous studies (Mannina et al., 2016b).

$R_{T}=\frac{T M P}{\left(Q_{O U T, i} / A\right) \cdot \mu}$

where $\mathrm{A}\left[\mathrm{m}^{2}\right]$ represents the membrane surface, $\mu[\mathrm{Pa} \mathrm{s}]$ is the permeate viscosity; the unit of the TMP is Pascal [Pa], Qout,i is expressed as cubic meter per second $\left[\mathrm{m}^{3} \mathrm{~s}^{-1}\right]$.

\subsection{Model calibration}

The model calibration has been performed by adopting a calibration protocol developed during previous studies (Mannina et al., 2011b). According to this protocol model factors are calibrated on the basis of a calibration hierarchy (Mannina et al., 2011b). To set up the hierarchy, a global sensitivity analysis (GSA) is performed choosing the widest literature range of model factors.

The standardized regression coefficient (SRC) method has been adopted to select important model factors (Saltelli et al., 2004). The SRC method allows to define a multivariate linear regression model (established for each model output on the basis of the randomly sampled value of the model factors).

The slope of the regression (SRC or $\beta \mathrm{i}$ ) provides information on the influence of each model factor on the model output variation (sensitivity). The sign of $\beta_{\mathrm{i}}$ indicates if the model factor "i" has positive $(+)$ or negative $(-)$ influence on the considered model output. In case of linear model (regression $\mathrm{R}^{2}=1$ ) $\beta \mathrm{i}$ allows to discriminate between important and non-influential model factors. The SRC method can be applied also to non-linear models for identifying the important model factors (Vanrolleghem et al., 2015). To apply the SRC method, at least 500 to 1000 simulations are required as suggested in the literature (Vanrolleghem et al., 2015).

Apart the GSA, the calibration protocol considers the generalized likelihood uncertainty estimation (GLUE) methodology based on Monte Carlo simulations (Mannina et al., 2011b; Beven and Binley, 1992). For each Monte Carlo simulation model outputs are compared with the observed and a likelihood measure/efficiency is quantified. On the basis of the value of the likelihood measure/efficiency the results are considered acceptable or not acceptable. In this study the same likelihood measure as adopted by Mannina et al. (2011b) was used.

\subsubsection{Uncertainty analysis}

Regarding the uncertainty analysis, non important factors have been fixed to their default or trial and error calibration value. Only important model factors have been considered during the uncertainty analysis. Specifically, important model factors were varied within an uncertainty range according to a random sampling. The results of the Monte Carlo simulations were analyzed on the basis of cumulative distribution function (CDF) for each model output. The 5th and 95th percentiles were also evaluated.

\subsection{Model application and numerical settings}

Input time series established on the basis of the influent wastewater measured data was adopted as model input data. 
Simulation period has the duration of 84 days. Four different sections of the SB-MBR plant were considered, in particular, the anoxic tank (Section 1), aerobic tank (Section 2), MBR tank (Section 3) and permeate tank (Section 4). The average values of the simulated time series for each model output were considered for the SRC application. Nineteen model outputs of the biological sub-model were considered for the GSA: COD $_{\text {TOT }}$ for all the four sections; $\mathrm{COD}_{\text {sol }}$ for Sections 1,2, and 3; $\mathrm{S}_{\mathrm{NO} 3}$ for Sections 1,3 and 4; ammonia $\left(\mathrm{S}_{\mathrm{NH} 4}\right)$ for Sections 3 and 4; total nitrogen (TN) for the Section 4; total suspended solids ( $\mathrm{X}_{\mathrm{TSS}}$ ) for Sections 1 and 2; $\mathrm{S}_{\mathrm{N} 2 \mathrm{O}}$ for Sections 1 and 2 and $\mathrm{S}_{\mathrm{GHG}, \mathrm{N} 2 \mathrm{O}}$ for Sections 1 and 2. Further one model output of the physical sub-model was also considered: membrane total resistance $\left(R_{T}\right)$. To apply the SRC method, 1200 model simulations were performed. According to the literature suggestion, a threshold value of 0.1 was chosen for the absolute value of $\beta_{\mathrm{i}}$ to discriminate between important and non important model factors (Varolleghem et al., 2015; Cosenza et al., 2013). Model calibration has been performed by running for each calibration step, 8000 Monte Carlo simulations. This number was established by increasing the sample dimension from 100 to 8000 and verifying that the maximum efficiency was constant. The same number of Monte Carlo simulations was adopted for each calibration step.
Uncertainty bands have been performed by employing 1000 Monte Carlo runs by varying only the most important model factors for all the model outputs taken into account. This number of Model Carlo runs was selected after verifying (sample dimensions between 100 and 1000) that the uncertainty analysis was not affected by any bias caused by the number of Monte Carlo simulations (Bertrand-Krajewski et al., 2002; Dotto et al., 2012). The uncertainty bands were calculated by adopting the likelihood distributions for each simulation time step and for each model output were then used for calculating uncertainty bands ( $5 \%$ percentile and $95 \%$ percentile of the 1000 runs for each model outputs).

\section{Results and discussion}

\subsection{Sensitivity analysis}

Table 1 summarizes the parameters selected as important at least for one model output. The application of the SRC method yielded for each model output taken into account an $R^{2}$ value around to 0.5 (Table 1 ).

By applying the SRC method 33 model factors have been selected to be important for at least one of the model output taken

Table 1

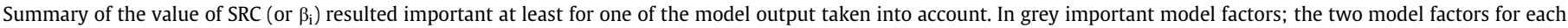
model outputs having the highest $\beta_{\mathrm{i}}$ value.

\begin{tabular}{|c|c|c|c|c|c|c|c|c|c|c|c|c|c|c|c|c|c|c|c|c|c|}
\hline \multirow[b]{3}{*}{$\mathrm{R}^{2}$} & \multicolumn{6}{|c|}{ ANOXIC - SECTION 1} & \multicolumn{5}{|c|}{ AEROBIC- SECTION 2} & \multicolumn{6}{|c|}{ MBR - SECTION 3} & \multicolumn{4}{|c|}{ PERMEATE - SECTION 4} \\
\hline & $\mathrm{COD}_{\mathrm{TOT}, 1}$ & $\mathrm{COD}_{\mathrm{sO}, 1}$ & $\mathrm{~S}_{\mathrm{NO} 3,1}$ & $\mathrm{MLSS}_{, 1}$ & $\mathrm{~S}_{\mathrm{GHG}, \mathrm{N2O}, 1}$ & $\mathrm{~S}_{\mathrm{N} 20,1}$ & $\mathrm{COD}_{\mathrm{TOT}, 2}$ & $\mathrm{COD}_{\mathrm{sOL}, 2}$ & $\mathrm{MLSS}_{, 2}$ & $\mathrm{~S}_{\mathrm{GHG}, \mathrm{N} 2 \mathrm{O}, 2}$ & $\mathrm{~S}_{\mathrm{N} 20,2}$ & $\mathrm{COD}_{\mathrm{TOT}, 3}$ & $\mathrm{COD}_{\mathrm{sOL}, 3}$ & $\mathrm{~S}_{\mathrm{NH} 3,3}$ & $\mathrm{~S}_{\mathrm{NO} 3,3}$ & $\mathrm{~S}_{\mathrm{GHG}, \mathrm{N} 2 \mathrm{O}, 3}$ & $\mathrm{~S}_{\mathrm{N} 20,3}$ & $\mathrm{COD}_{\mathrm{SOL}, 4}$ & $\mathrm{TN}_{, 4}$ & $\mathrm{~S}_{\mathrm{NO}, 4}$ & $\mathrm{R}_{\mathrm{T}}$ \\
\hline & 0.46 & 0.55 & \begin{tabular}{|l|l}
0.48 \\
\end{tabular} & 0.45 & 0.48 & 0.42 & 0.44 & 0.52 & 0.46 & 0.55 & 0.48 & 0.45 & 0.58 & 0.44 & 0.42 & 0.52 & 0.48 & 0.48 & 0.55 & 0.44 & 0.62 \\
\hline factor & \multicolumn{6}{|c|}{ SRC } & \multicolumn{5}{|c|}{ SRC } & \multicolumn{6}{|c|}{ SRC } & \multicolumn{4}{|c|}{ SRC } \\
\hline$f_{\text {UAP }}$ & 0.02 & -0.12 & 0.56 & -0.08 & -0.09 & 0.46 & 0.06 & -0.13 & -0.07 & 0.39 & -0.20 & 0.05 & -0.16 & 0.19 & 0.75 & 0.01 & 0.05 & 0.28 & 0.63 & 0.75 & 0.47 \\
\hline$i_{N, S s}$ & 0.03 & 0.65 & 0.79 & -0.33 & -0.01 & 0.04 & 0.10 & 0.65 & -0.33 & -0.02 & 0.00 & 0.09 & 0.62 & 0.74 & 0.70 & -0.05 & 0.00 & 0.07 & -0.16 & 0.70 & 0.03 \\
\hline $\mathrm{i}_{\mathrm{N}, \mathrm{xs}}$ & 0.08 & 0.29 & -0.19 & 0.13 & 0.15 & 0.31 & 0.25 & 0.30 & 0.13 & 0.14 & 0.99 & 0.24 & 0.26 & -0.23 & -0.23 & 0.00 & 0.02 & 0.70 & -0.17 & -0.23 & 0.03 \\
\hline $\mathrm{i}_{\mathrm{TSS}, \mathrm{xi}}$ & 0.01 & -0.03 & -0.03 & 0.01 & 0.15 & -0.28 & 0.01 & -0.03 & 0.01 & -0.50 & -0.89 & 0.01 & -0.03 & -0.02 & -0.03 & 0.05 & 0.02 & -0.01 & -0.02 & -0.03 & -0.01 \\
\hline $\mathrm{Y}_{\mathrm{A}, \mathrm{NOB}}$ & -0.02 & 0.03 & 0.03 & -0.02 & -0.41 & 0.92 & -0.02 & 0.02 & -0.02 & 0.11 & -0.15 & -0.02 & 0.03 & 0.03 & 0.04 & 0.02 & 0.01 & 0.00 & -0.06 & 0.04 & 0.00 \\
\hline $\mathrm{k}_{\mathrm{o}, \mathrm{HYDR}}$ & 0.02 & 0.00 & -0.05 & 0.02 & 0.28 & -0.56 & 0.02 & 0.00 & 0.02 & 0.19 & 0.77 & 0.02 & 0.00 & -0.04 & -0.05 & 0.02 & 0.03 & 0.00 & 0.02 & -0.05 & 0.00 \\
\hline $\mathrm{k}_{\mathrm{NO}, \mathrm{HYOR}}$ & 0.00 & 0.00 & 0.00 & 0.01 & 0.13 & 0.37 & 0.00 & 0.00 & 0.01 & -0.15 & 0.24 & 0.00 & 0.00 & 0.02 & -0.01 & 0.01 & 0.01 & 0.01 & 0.03 & -0.01 & 0.01 \\
\hline $\mathrm{i}_{\mathrm{TSS}, \mathrm{BM}}$ & -0.06 & -0.24 & -0.28 & -0.20 & -0.01 & -0.03 & -0.18 & -0.22 & -0.21 & 0.00 & 0.00 & -0.17 & -0.20 & -0.16 & -0.37 & 0.02 & 0.00 & -0.34 & 0.82 & -0.37 & -0.02 \\
\hline$\mu_{H}$ & 1.00 & 0.05 & -0.29 & -0.32 & -0.02 & -0.01 & -0.50 & 1.00 & -0.31 & -0.02 & -0.01 & -0.50 & 0.04 & -0.17 & -0.32 & 0.02 & -0.02 & 0.25 & -0.58 & -0.32 & 0.12 \\
\hline$\eta_{\mathrm{g} 3}$ & 0.33 & -0.39 & 0.50 & 0.90 & 0.95 & 0.60 & 0.97 & -0.37 & 0.90 & -0.49 & -0.09 & 0.97 & -0.37 & 0.37 & 0.45 & 0.02 & 0.01 & -0.15 & -0.21 & 0.45 & -0.07 \\
\hline$\eta_{\mathrm{g} 4}$ & 0.33 & 0.29 & -0.08 & 0.84 & 0.86 & 0.16 & 0.99 & 0.30 & 0.84 & -0.17 & -0.29 & 0.99 & 0.32 & -0.21 & -0.10 & 0.01 & 0.00 & -0.08 & -0.09 & -0.10 & -0.04 \\
\hline $\mathrm{k}_{\mathrm{NO3}}$ & 0.01 & 0.02 & -0.05 & 0.03 & 0.50 & -0.76 & 0.01 & 0.02 & 0.03 & 0.01 & 1.00 & 0.01 & 0.02 & -0.04 & -0.05 & 0.01 & 0.01 & 0.02 & -0.01 & -0.05 & 0.02 \\
\hline $\mathrm{k}_{\mathrm{NO} 2}$ & 0.11 & 1.00 & 0.07 & 0.14 & 0.15 & 0.00 & 0.34 & 0.10 & 0.13 & 0.25 & -0.14 & 0.34 & 1.00 & 0.04 & -0.03 & 0.01 & 0.05 & 0.48 & 0.04 & -0.03 & 0.02 \\
\hline $\mathrm{k}_{\mathrm{N} 2 \mathrm{O}}$ & 0.23 & 0.77 & 0.78 & 0.30 & 0.36 & 1.00 & 0.69 & 0.78 & 0.29 & 1.00 & 0.39 & 0.67 & 0.75 & 0.93 & 0.53 & 0.04 & 0.03 & 0.15 & 0.02 & 0.53 & 0.05 \\
\hline $\mathrm{k}_{\text {Взмо }}$ & 0.00 & 0.03 & -0.02 & 0.00 & -0.12 & -0.20 & 0.00 & 0.03 & 0.00 & 0.44 & 0.12 & 0.00 & 0.03 & 0.00 & -0.04 & 0.02 & 0.00 & 0.01 & -0.03 & -0.04 & 0.01 \\
\hline$k_{A L K, H}$ & 0.30 & -0.34 & -0.74 & 1.00 & 1.00 & -1.25 & 0.89 & -0.32 & 1.00 & 0.70 & 0.55 & 0.89 & -0.31 & -0.44 & -0.78 & 0.04 & 0.01 & -0.09 & 0.25 & -0.78 & -0.04 \\
\hline$K_{\mathrm{H}, \text { UAP }}$ & 0.07 & 0.01 & 0.34 & 0.08 & 0.01 & 0.00 & 0.20 & 0.85 & 0.07 & -0.01 & 0.03 & 0.20 & 0.02 & 0.48 & 0.18 & 0.00 & -0.02 & 0.36 & 0.82 & 0.18 & 0.59 \\
\hline$\mu_{\text {AUT, }, 0 B}$ & 0.01 & -0.01 & 0.03 & 0.01 & 0.24 & 0.34 & 0.01 & -0.01 & 0.01 & 0.71 & 0.00 & 0.01 & -0.01 & 0.03 & 0.03 & 0.03 & 0.01 & 0.01 & 0.03 & 0.03 & 0.01 \\
\hline$\mu_{\text {AUT,NOB }}$ & 0.16 & 0.40 & 0.54 & 0.07 & 0.09 & 0.64 & 0.47 & 0.41 & 0.07 & 0.31 & -0.08 & 0.46 & 0.39 & 0.74 & 1.00 & 1.00 & 1.00 & 0.69 & -0.06 & 0.39 & 0.33 \\
\hline $\mathrm{K}_{\mathrm{FA}}$ & -0.28 & 0.88 & 1.00 & -0.69 & -0.04 & 0.01 & -0.82 & 0.83 & -0.69 & -0.03 & -0.01 & -0.82 & 0.85 & -0.22 & -0.04 & 0.01 & 0.00 & 0.04 & 0.38 & -0.04 & 0.02 \\
\hline $\mathrm{Ki} 9_{\mathrm{FA}}$ & -0.01 & -0.87 & -0.26 & 0.16 & 0.01 & -0.02 & -0.02 & -0.83 & 0.16 & -0.01 & 0.01 & -0.02 & -0.88 & -0.27 & -0.23 & -0.01 & -0.04 & 0.40 & 1.00 & -0.23 & 0.02 \\
\hline$k_{\text {fna }}$ & -0.24 & 0.88 & -0.20 & -0.45 & -0.52 & 0.73 & -0.72 & 0.09 & -0.45 & -0.12 & 0.40 & -0.72 & 0.85 & -0.18 & -0.15 & 0.04 & 0.00 & 0.33 & 0.72 & -0.15 & 0.02 \\
\hline $\mathrm{Ki}^{\mathrm{i}} 10_{\mathrm{FA}}$ & -0.18 & -0.32 & -0.24 & -0.05 & -0.02 & -0.01 & -0.53 & -0.28 & -0.05 & -0.07 & -0.04 & -0.53 & -0.28 & -0.17 & -0.76 & -0.02 & -0.01 & 0.05 & 0.79 & -0.76 & 0.03 \\
\hline$k_{\text {i10fna }}$ & -0.02 & -0.02 & -0.04 & 0.00 & -0.09 & -0.82 & -0.02 & -0.02 & 0.00 & -0.23 & -0.46 & -0.02 & -0.02 & -0.03 & -0.05 & 0.05 & 0.02 & 1.00 & 0.88 & -0.54 & 0.07 \\
\hline$f$ & 0.11 & -0.07 & -0.48 & 0.23 & 0.01 & -0.01 & 0.33 & -0.07 & 0.23 & -0.01 & -0.01 & 0.33 & -0.08 & -0.54 & -0.54 & 0.01 & 0.03 & 0.01 & 0.05 & -0.03 & 0.01 \\
\hline$\alpha$ & 0.00 & 0.01 & -0.01 & 0.00 & -0.11 & 0.58 & 0.00 & 0.01 & 0.00 & -0.39 & -0.23 & 0.00 & 0.01 & -0.02 & 0.00 & 0.01 & 0.05 & 0.02 & 0.01 & 0.00 & 0.02 \\
\hline$\lambda$ & 0.16 & 0.24 & 0.10 & 0.07 & 0.15 & 0.86 & 0.48 & 0.27 & 0.06 & 0.16 & -0.44 & 0.47 & 0.23 & 1.00 & 0.17 & 0.06 & 0.01 & 0.74 & -0.25 & 1.00 & 0.35 \\
\hline $\mathrm{F}_{\mathrm{xi}}$ & 0.04 & 0.01 & -0.01 & 0.03 & 0.63 & -0.70 & 0.04 & 0.01 & 0.03 & 0.19 & -0.71 & 0.04 & 0.01 & -0.03 & 0.00 & 0.02 & 0.04 & 0.00 & 0.02 & 0.00 & 0.00 \\
\hline$I_{S, H}$ & -0.02 & -0.01 & -0.06 & -0.01 & -0.28 & -0.16 & -0.02 & -0.01 & -0.01 & -0.14 & 0.70 & -0.02 & -0.01 & -0.07 & -0.06 & 0.05 & 0.03 & 0.00 & -0.01 & -0.06 & 0.00 \\
\hline $\mathrm{k}_{2,2}$ & 0.00 & 0.03 & -0.02 & 0.00 & -0.10 & 0.39 & 0.00 & 0.03 & 0.00 & -0.45 & 0.79 & 0.00 & 0.03 & -0.02 & -0.02 & 0.04 & 0.02 & 0.01 & -0.05 & -0.02 & 0.01 \\
\hline $\mathrm{k}_{2,3}$ & 0.03 & -0.02 & 0.00 & 0.03 & 0.60 & 0.53 & 0.03 & -0.02 & 0.03 & 0.48 & -0.44 & 0.03 & -0.02 & 0.00 & 0.00 & 0.03 & 0.04 & 0.02 & -0.01 & 0.00 & 0.02 \\
\hline$C_{E}$ & 0.15 & -0.15 & 0.03 & 0.28 & 0.01 & 0.00 & 0.45 & -0.13 & 0.28 & 0.02 & -0.03 & 0.44 & -0.15 & -0.01 & -0.07 & 0.03 & 0.01 & 0.36 & 0.75 & -0.07 & -1.00 \\
\hline$f_{x i}$ & 0.34 & 0.13 & -0.22 & 0.60 & 0.00 & 0.01 & 1.00 & 0.14 & 0.60 & 0.00 & 0.01 & 1.00 & 0.14 & -0.53 & -0.03 & -0.02 & -0.03 & -0.07 & 0.37 & -0.03 & -0.03 \\
\hline
\end{tabular}




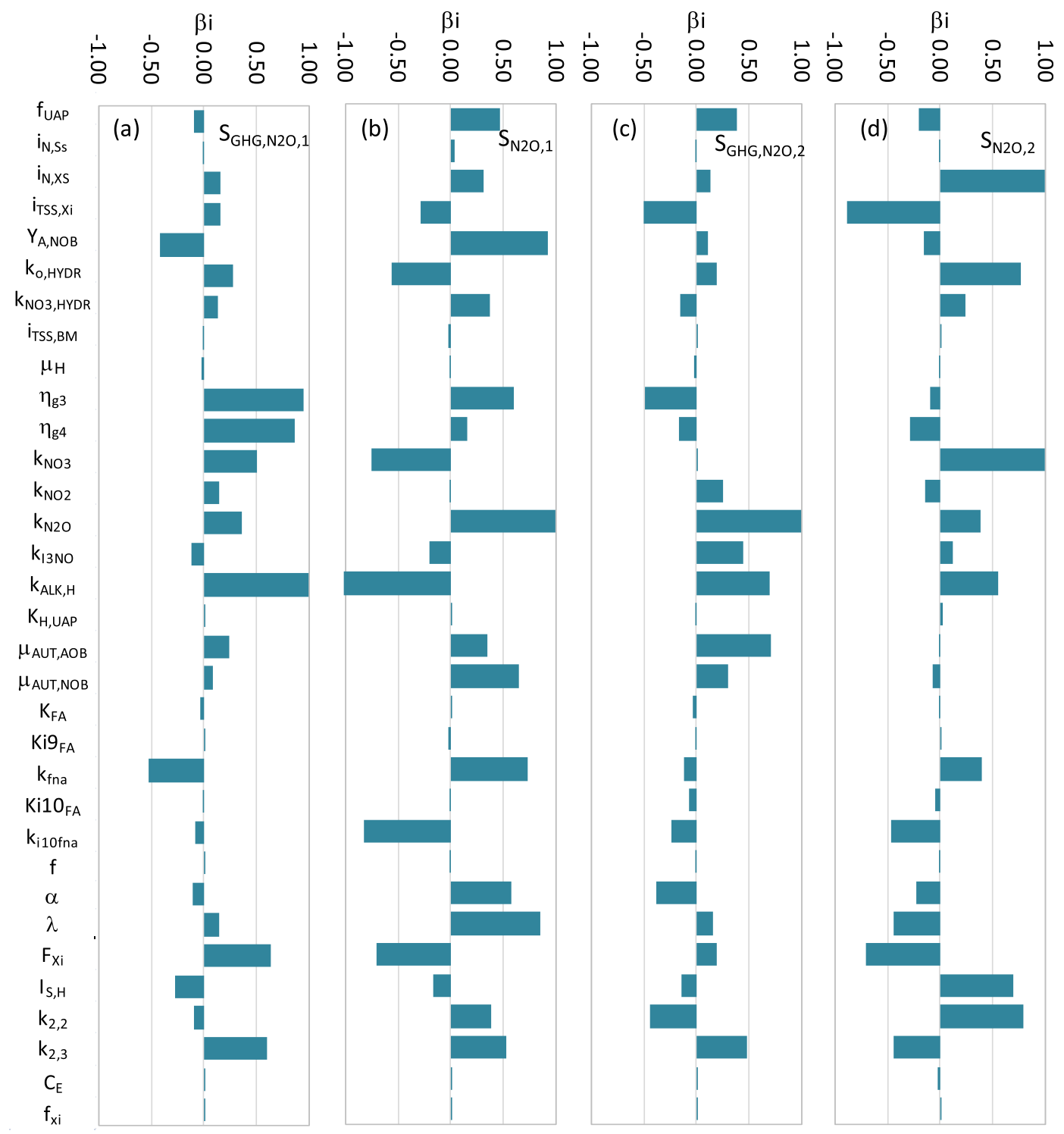

Fig. 3. Results related to the $S R C$ application for $\mathrm{S}_{\mathrm{GHG}, \mathrm{N} 2 \mathrm{O}, 1}$ (a), $\mathrm{S}_{\mathrm{N} 2 \mathrm{O}, 1}$ (b), $\mathrm{S}_{\mathrm{GHG}, \mathrm{N} 2 \mathrm{O}, 2}$ (c), $\mathrm{S}_{\mathrm{N} 2 \mathrm{O}, 2}$ (d) model outputs.

into account. For sake of conciseness only the key model outputs for each plant section are discussed below.

Fig. 3 shows the results related to the important model factors at least for one of the model outputs considered: $S_{\mathrm{N} 2 \mathrm{O}, 1}(\mathrm{a}), \mathrm{S}_{\mathrm{GHG}}$, $\mathrm{N} 2 \mathrm{O}, 1$ (b), $\mathrm{S}_{\mathrm{N} 2 \mathrm{O}, 2}$ (c) and $\mathrm{S}_{\mathrm{GHG}, \mathrm{N} 2 \mathrm{O}, 2}$ (d). For the meaning of the symbols reported in Fig. 3 the reader is referred to Table A.1. Among the important model factors, some deserve to be discussed. The group of half saturation coefficients $\left(\mathrm{k}_{\mathrm{N} 2 \mathrm{O}}, \mathrm{k}_{\mathrm{NO} 3}, \mathrm{k}_{\mathrm{ALK}}\right)$ (related with the $\mathrm{S}_{\mathrm{N} 2 \mathrm{O}}, \mathrm{S}_{\mathrm{NO} 3}$ and $\mathrm{S}_{\mathrm{ALK}}$ ) have a great influence on all the model outputs considered. Such a result corroborates the literature findings, which suggest to focus the attention on the half-saturation coefficients of the biological processes involving nitrogen due to their high uncertain degree (Sweetapple et al., 2013). Therefore, it is advisable to experimentally quantify these factors. The model factors $\mu_{\text {AUT,AOB }}$ and $\mu_{\text {AUT,NOB }}$ mostly affect (positively) the $S_{\mathrm{N} 20,1}$ and $\mathrm{S}_{\mathrm{GHG}, \mathrm{N} 2 \mathrm{O}, 2}$. Such a result shows an indirect effect for $\mathrm{S}_{\mathrm{N} 2 \mathrm{O}, 1}$. Indeed, with the increasing of the autotrophic maximum specific growth rate the availability of nitrate inside the aerobic tank increases with a consequent increase of $\mathrm{S}_{\mathrm{N} 2 \mathrm{O}, 1}$ produced during the denitrification for example due to the scares availability of substrate. The importance of the factors $\eta_{\mathrm{g} 3}$ and $\eta_{\mathrm{g} 4}$ for $\mathrm{S}_{\mathrm{GHG}, \mathrm{N} 2 \mathrm{O}, 1}$ is of relevant interest. Indeed, these latter factors control the rate of the hetero- trophic anoxic processes on the substrate $\left(S_{S}\right)$ when $S_{\mathrm{NO} 2}$ (nitrite) is reduced to $S_{\mathrm{NO}}\left(\eta_{\mathrm{g} 3}\right)$ and when $S_{\mathrm{NO}}\left(\eta_{\mathrm{g} 4}\right)$ is reduced into $S_{\mathrm{N} 2 \mathrm{O}}$. Thus, consequently $\eta_{\mathrm{g} 3}$ and $\eta_{\mathrm{g} 4}$ influence the amount of gaseous $\mathrm{N}_{2} \mathrm{O}$ emitted from the anoxic tank $\left(\mathrm{S}_{\mathrm{GHG}, \mathrm{N} 2 \mathrm{O}, 1}\right)$. Both $\mathrm{k}_{2,2}$ and $\mathrm{k}_{2,3}$ (coefficients for oxygen transfer of the aerobic tank and MBR tank, respectively) have positive effect on $\mathrm{S}_{\mathrm{N} 2 \mathrm{O}, 1}$. This result is due to the increase of mainly debited to the increase of the amount of nitrate and dissolved oxygen recycled into the anoxic tank with the increasing of the oxygen concentration inside the aerobic and MBR tanks. Therefore, the $\mathrm{N}_{2} \mathrm{O}$ can be also produced due to the AOB contribution inside the anoxic tank (in case the environment become aerobic).

Thus, the role of $\mathrm{k}_{2,2}$ and $\mathrm{k}_{2,3}$ on $\mathrm{S}_{\mathrm{N} 2 \mathrm{O}, 1}$ is mainly indirect. Indeed, with the increase of $k_{2,3}$ the amount of the available oxygen inside the aerobic tank increases with a consequent complete nitrification. Therefore, the amount of nitrate to be denitrified in the anoxic tank increases; nitrate could not be completely denitrified due to the poor availability of carbon. On the other hand, with the increase of $k_{2,3}$ the amount of mass oxygen recycled from the MBR to the anoxic tank (through the ODR) increases. The importance of the factors affecting the oxygen transfer rate in the aerated tank suggests that in order to better predict $\mathrm{N}_{2} \mathrm{O}$ emissions of a 
WWTP a detailed knowledge on the oxygen transfer has to be acquired.

As can be additionally noted from Fig. 3, the autotrophic salinity inhibition coefficient $\left(\mathrm{I}_{\mathrm{s}, \mathrm{H}}\right)$ positively influences the $\mathrm{N}_{2} \mathrm{O}$ production inside the aerobic tank. Indeed, several studies have demonstrated that the salinity could promote the $\mathrm{N}_{2} \mathrm{O}$ production during the nitrification (Zhao et al., 2014). It is interesting to note that factors related to the physical model ( $\alpha$ and $\lambda$, representing the stickiness of the biomass particles and the screening parameter, respectively) affect both $\mathrm{S}_{\mathrm{N} 2 \mathrm{O}, 1}$ (Fig. 3). Such a result is mainly debited to the role of the membrane in retaining the substrate that will be or not available for the nitrate denitrification.

Model factors mostly affecting the model output $\mathrm{COD}_{\mathrm{TOT}, 1}$ and $\mathrm{COD}_{\mathrm{SOL} 2}$ is $\mu_{\mathrm{H}}$ (Table 1 ). Indeed, the $\beta_{\mathrm{i}}$ value of $\mu_{\mathrm{H}}$ for both $\mathrm{COD}_{\mathrm{TOT}, 1}$ and $\mathrm{COD}_{\mathrm{SOL}, 2}$ is equal to 1 ; having a positive influence. Indeed, with the increasing of the maximum growth rate of heterotrophic bacteria the increase of the particle fraction of COD takes place. Further, $\mathrm{COD}_{\mathrm{TOT}, 1}$ is also affected by $\eta_{\mathrm{g} 3}$ and $\eta_{\mathrm{g} 4}$ which respectively control the rate of the heterotrophic anoxic growth when $\mathrm{S}_{\mathrm{NO} 2}$ (nitrite) is reduced to $S_{\mathrm{NO}}\left(\eta_{\mathrm{g} 3}\right)$ and $\mathrm{S}_{\mathrm{NO}}\left(\eta_{\mathrm{g} 4}\right)$ is reduced into $\mathrm{S}_{\mathrm{N} 2 \mathrm{O}}$. The model output $\mathrm{S}_{\mathrm{NO}, 1}$ is mostly influenced by the half saturation coefficients for free ammonia $\left(\mathrm{K}_{\mathrm{FA}}\right)$ for nitrous oxide-nitrogen $\left(\mathrm{K}_{\mathrm{N} 2 \mathrm{O}}\right)$. Such a results is due to the fact that these coefficients control the amount of nitrate that can be produced inside the aerobic tank and consequently recycled inside the anoxic one. Similarly, $\mu_{\mathrm{AUT}, \mathrm{NOB}}$ and $\mathrm{i}_{\mathrm{N}, \mathrm{Ss}}$ influence the amount of nitrate that can be produced inside the aerobic tank and consequently $\mathrm{S}_{\mathrm{NO}, 1}$ (Table 1 ). Indeed, $\mu_{\mathrm{AUT}, \mathrm{NOB}}$ is the most important model factor for $\mathrm{S}_{\mathrm{NO}, 2}$ (Table 1 ). In terms of resistance, the set of the following model factors has been selected as important: $f_{U A P}$ (fraction of $\mathrm{S}_{\mathrm{UAP}}$ generated in biomass decay), $\mathrm{K}_{\mathrm{H}, \mathrm{UAP}}$ (hydrolysis rate coefficient for $S_{U A P}$ ), $\lambda$ (screening parameter) and $C_{E}$ (efficiency of backwashing) (Table 1 ). Among these factors $\mathrm{f}_{\text {UAP }}$ and $\mathrm{K}_{\mathrm{H}, \mathrm{UAP}}$ are related to the biological sub-model; $\mathrm{f}_{\mathrm{UAP}}$ and $\mathrm{K}_{\mathrm{H}, \mathrm{UAP}}$ positively influence $\mathrm{R}_{\mathrm{T}}$ due to the fact that with their increase, the increase of the $\mathrm{S}_{\mathrm{UAP}}$ production takes place. Thus influencing the membrane fouling. Such a result has paramount interest because suggests by reducing the SMP production a substantial reduction of the membrane resistance (which means a reduction of operational costs) can occur. Model factors $\lambda$ and $C_{E}$ are directly connected with the physical sub-model. The negative influence of $C_{E}$ is due to the fact that with the increase of the backwashing efficiency the amount of the cake layer deposited on the membrane surface decreases thus reducing the TMP value at fixed permeate flux.

\subsection{Model calibration results}

Model calibration has been performed by varying all the important model factors selected during the sensitivity analysis. All the other model factors have been fixed at their default value or at the value obtained during the initial trial and error calibration according to the calibration protocol (Mannina et al., 2011b). The model calibration has been performed by comparing simulated with measured data acquired during the sampling campaign. Simulations characterized by a model efficiency greater than 0.2 were selected as behavioral (Mannina et al., 2011b; Vanrolleghem et al., 2015). The selection of the calibrated factor values have been performed on the basis of the maximum model efficiency value.

In Table A.1, the final calibrated factor values are summarized along with the literature range. More precisely, only factors selected as influential have been calibrated (letter " $\mathrm{C}$ " in the line related to the source of Table A.1). Some model factors have been evaluated on the basis of mass balance continuity check as suggested by Vanrolleghem et al. (2005) (letter "M" in the line related to the source of Table A.1). All the other factors have been fixed at the literature value (letter "L" in the line related to the source of Table A.1).
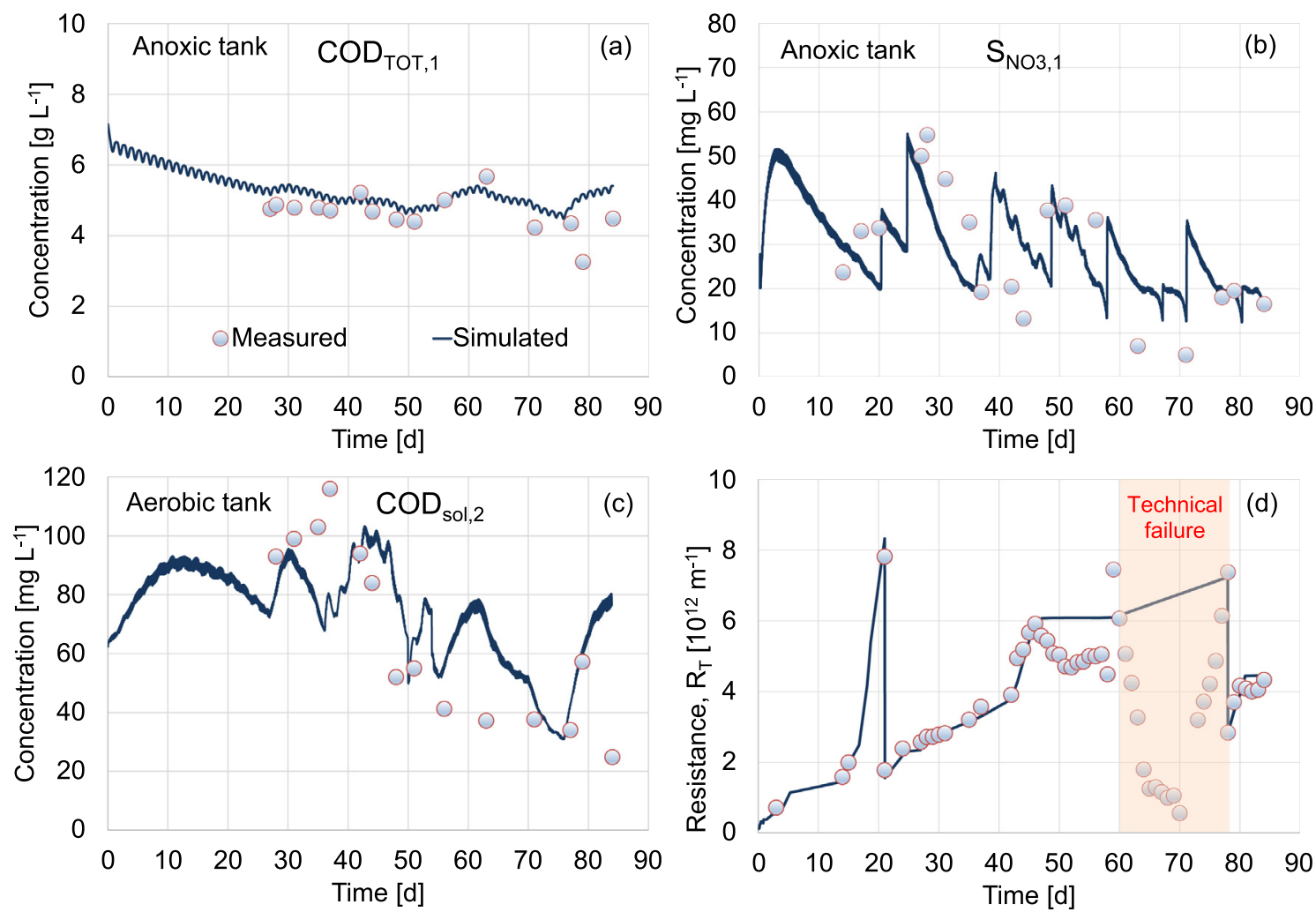

Fig. 4. Calibrated and measured pattern for $\operatorname{COD}_{\mathrm{TOT}, 1}(\mathrm{a}), \mathrm{S}_{\mathrm{NO}, 1,1}$ (b), $\mathrm{COD}_{\mathrm{sol}, 2}(\mathrm{c}), \mathrm{R}_{\mathrm{T}}(\mathrm{d}), \mathrm{S}_{\mathrm{N} 2 \mathrm{O}, 2}$ (e) and $\mathrm{S}_{\mathrm{GHG}, \mathrm{N} 2 \mathrm{O}, 2}$ (f). 

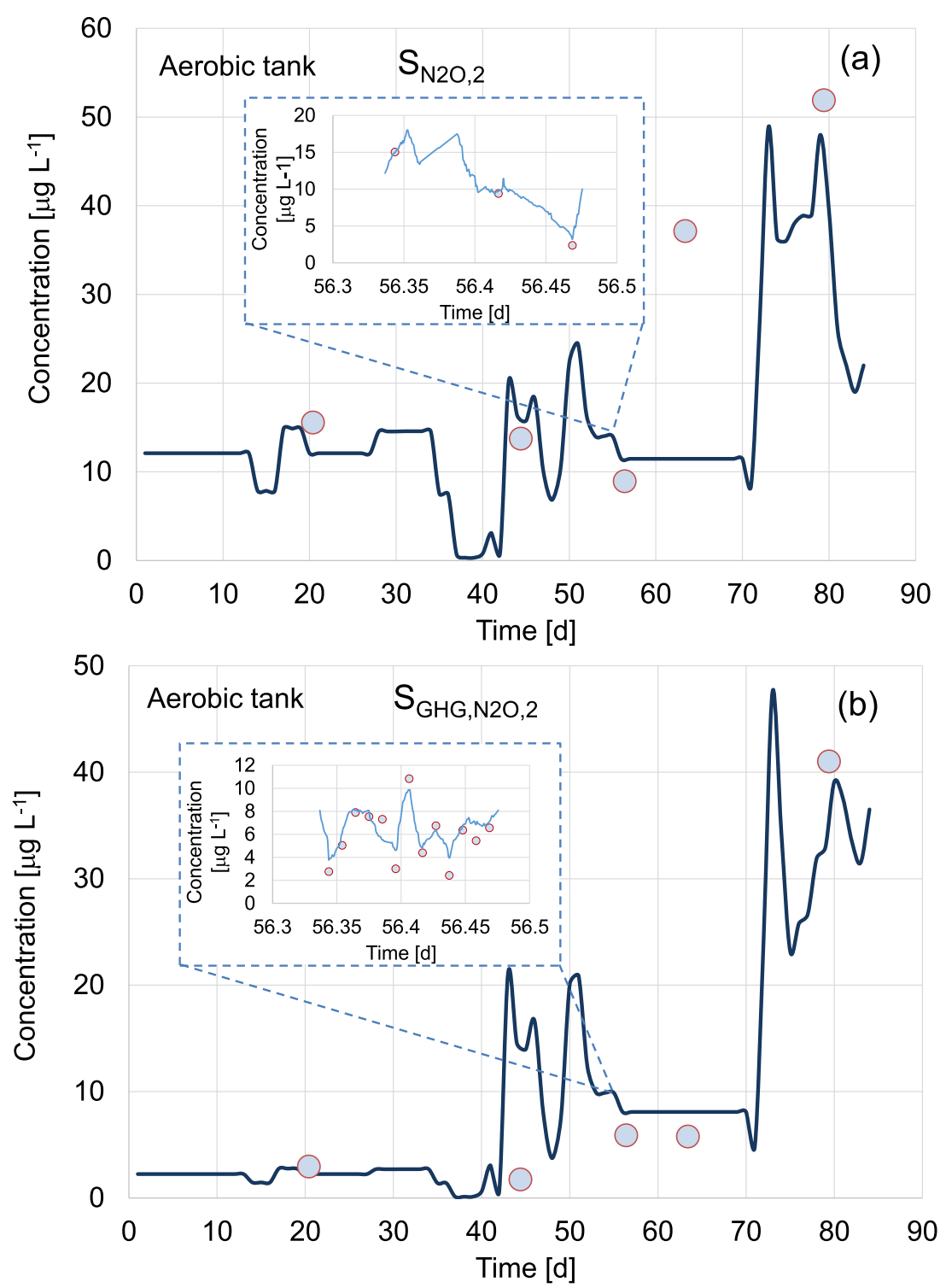

Fig. 5. Calibrated and measured pattern for $\mathrm{S}_{\mathrm{N} 2 \mathrm{O}, 2}(\mathrm{a})$ and $\mathrm{S}_{\mathrm{GHG}, \mathrm{N} 2 \mathrm{O}, 2}$ (b) (aerobic tank).

Table 2

Synthesis of efficiency for each measured state variable.

\begin{tabular}{|c|c|c|c|c|c|c|}
\hline Section & Anoxic tank & & & & & \\
\hline Model output & $\mathrm{COD}_{\mathrm{TOT}, 1}$ & $\mathrm{COD}_{\text {sol }, 1}$ & $\mathrm{X}_{\mathrm{TSS}, 1}$ & $\mathrm{~S}_{\mathrm{NO} 3,1}$ & $\mathrm{~S}_{\mathrm{GHG}, \mathrm{N} 2 \mathrm{O}, 1}$ & $\mathrm{~S}_{\mathrm{N} 2 \mathrm{O}, 1}$ \\
\hline Efficiency & 0.42 & 0.52 & 0.31 & 0.44 & 0.47 & 0.34 \\
\hline \# data & 14 & 14 & 16 & 17 & 65 & 15 \\
\hline Section & Aerobic tank & & & & & \\
\hline Model output & $\mathrm{COD}_{\mathrm{TOT}, 2}$ & $\mathrm{COD}_{\mathrm{sol}, 2}$ & $\mathrm{X}_{\mathrm{TSS}, 2}$ & $\mathrm{~S}_{\mathrm{GHG}, \mathrm{N} 2 \mathrm{O}, 2}$ & $\mathrm{~S}_{\mathrm{N} 2 \mathrm{O}, 2}$ & \\
\hline Efficiency & 0.46 & 0.52 & 0.46 & 0.49 & 0.39 & \\
\hline \# data & 14 & 14 & 14 & 65 & 15 & \\
\hline Section & MBR tank & & & & & \\
\hline Model output & $\mathrm{COD}_{\mathrm{TOT}, 3}$ & $\mathrm{COD}_{\mathrm{sol}, 3}$ & $\mathrm{~S}_{\mathrm{NH} 4,3}$ & $\mathrm{~S}_{\mathrm{NO} 3,3}$ & & \\
\hline Efficiency & 0.25 & 0.29 & 0.31 & 0.28 & & \\
\hline \# data & 8 & 8 & 8 & 8 & & \\
\hline Section & Permeate & & & & & \\
\hline Model output & $\mathrm{COD}_{\mathrm{TOT}, 4}$ & $\mathrm{~S}_{\mathrm{NH} 4,4}$ & $\mathrm{~S}_{\mathrm{NO}, 4}$ & $\mathrm{TN}_{, 4}$ & $\mathrm{R}_{\mathrm{T}}$ & \\
\hline Efficiency & 0.35 & 0.34 & 0.36 & 0.3 & 0.79 & \\
\hline \# data & 15 & 17 & 17 & 12 & 55 & \\
\hline
\end{tabular}



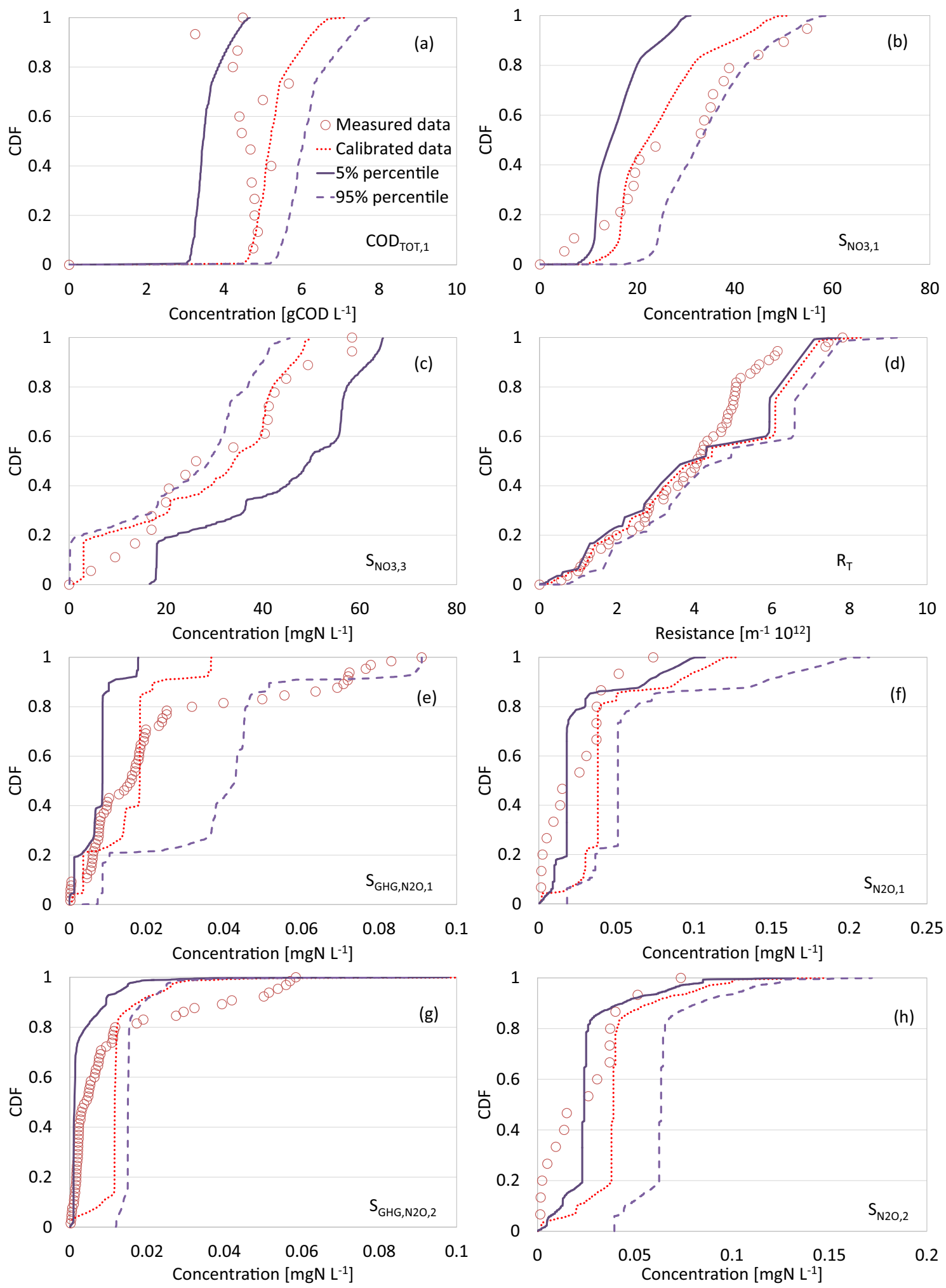

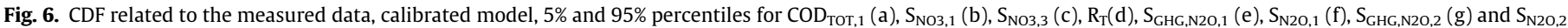
(h).

Some calibrated factors merit to be further discussed. More precisely, regarding the salinity inhibition factors one can observe that the inhibition factors related to the heterotrophic biomass $\left(\mathrm{I}_{\mathrm{S}, \mathrm{H}}\right)$ is lower than that related to the autotrophic biomass $\left(\mathrm{I}_{\mathrm{S}, \mathrm{A}}\right)$. Indeed, salinity has a inhibition effect on autotrophic biomass growth than on the heterotrophic biomass (Luo et al., 2015; Mannina et al., 2016b). More precisely, the salinity increase causes the cell plasmolysis and/or the loss of metabolic activity for autotrophic biomass (Johir et al., 2013). Therefore, the values of the maximum specific growth rate of $\mathrm{X}_{\mathrm{AOB}}$ and $\mathrm{X}_{\mathrm{NOB}}$ were lower when adjusted for salt concentration $\mathrm{I}_{\mathrm{S}, \mathrm{A}}$. For example, the final value related to the $\mathrm{X}_{\mathrm{AOB}}$ was equal to $0.68 \mathrm{~d}^{-1}$, which decreases to $0.48 \mathrm{~d}^{-1}$ due 
Table A.1

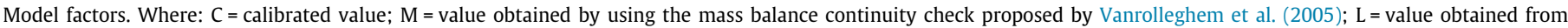
technical literature.

\begin{tabular}{|c|c|c|c|c|c|c|c|}
\hline Description & & Symbol & Unit & Range & Reference & $\begin{array}{l}\text { Value } \\
\mathrm{T}=20^{\circ} \mathrm{C}\end{array}$ & Source \\
\hline \multirow[t]{21}{*}{ Stoichiometric } & Fraction of $S_{I}$ generated in biomass decay & $\mathrm{f}_{\mathrm{SI}}$ & $g S_{I} g \cdot X_{H}^{-1}$ & $0 \div 0.01$ & Hauduc et al. (2010) & 0 & $\mathrm{~L}$ \\
\hline & Yield for $\mathrm{X}_{\mathrm{H}}$ growth & $\mathrm{Y}_{\mathrm{H}}$ & $\mathrm{g} \mathrm{X}_{\mathrm{H}} \cdot \mathrm{g} \mathrm{X}_{\mathrm{S}}^{-1}$ & $0.38 \div 0.75$ & Hauduc et al. (2010) & 0.39 & $\mathrm{~L}$ \\
\hline & Fraction of $X_{I}$ generated in biomass decay & $\mathrm{f}_{\mathrm{XI}}$ & $\mathrm{g} \mathrm{X}_{\mathrm{I}} \cdot \mathrm{g} \mathrm{X}_{\mathrm{H}}^{-1}$ & $0.05 \div 0.15$ & Hauduc et al. (2010) & 0.055 & $\mathrm{C}$ \\
\hline & Fraction of $\mathrm{S}_{\mathrm{BAP}}$ generated in biomass decay & $f_{\mathrm{BAP}}$ & - & $0.020 \div 0.023$ & $\begin{array}{l}\text { Mannina and } \\
\text { Cosenza, } 2015\end{array}$ & 0.007 & $\mathrm{~L}$ \\
\hline & Fraction of $\mathrm{S}_{\mathrm{UAP}}$ generated in biomass decay & $\mathrm{f}_{\mathrm{UAP}}$ & - & $0.005 \div 0.150$ & $\begin{array}{l}\text { Mannina and } \\
\text { Cosenza, } 2015\end{array}$ & 0.149 & $\mathrm{C}$ \\
\hline & $\mathrm{N}$ content of $\mathrm{S}_{\mathrm{s}}$ & $\mathrm{i}_{\mathrm{N}, \mathrm{Ss}}$ & g N.g S $S_{s}^{-1}$ & $0.08 \div 0.12$ & Hauduc et al. (2010) & 0.082 & $\mathrm{C}$ \\
\hline & $\mathrm{N}$ content of $\mathrm{S}_{\mathrm{I}}$ & $\mathrm{i}_{\mathrm{N}, \mathrm{SI}}$ & g N.g S ${ }^{-1}$ & $0.025 \div 0.035$ & Hauduc et al. (2010) & 0.025 & $\mathrm{~L}$ \\
\hline & $\mathrm{N}$ content of $\mathrm{X}_{\mathrm{I}}$ & $\mathrm{i}_{\mathrm{N}, \mathrm{XI}}$ & g N.g X $\mathrm{I}^{-1}$ & $0.015 \div 0.025$ & Hauduc et al. (2010) & 0.015 & $\mathrm{~L}$ \\
\hline & $\mathrm{N}$ content of $\mathrm{X}_{\mathrm{S}}$ & $\mathrm{i}_{\mathrm{N}, \mathrm{XS}}$ & g N.g X $X_{S}^{-1}$ & $0.03 \div 0.05$ & Hauduc et al. (2010) & 0.047 & $\mathrm{C}$ \\
\hline & $\mathrm{N}$ content of biomass & $\mathrm{i}_{\mathrm{N}, \mathrm{BM}}$ & g N.g X $X_{B M}^{-1}$ & $0.0665 \div 0.0735$ & Hauduc et al. (2010) & 0.068 & $\mathrm{~L}$ \\
\hline & Conversion factor $\mathrm{X}_{\mathrm{I}}$ in TSS & $\mathrm{i}_{\mathrm{TSS}, \mathrm{XI}}$ & g TSS.g XI & $0.7125 \div 0.7875$ & Hauduc et al. (2010) & 0.74 & $\mathrm{C}$ \\
\hline & Conversion factor $\mathrm{X}_{\mathrm{S}}$ in TSS & $\mathrm{i}_{\mathrm{TSS}, \mathrm{XS}}$ & g TSS.g X $\mathrm{S}^{-1}$ & $0.7125 \div 0.7875$ & Hauduc et al. (2010) & 0.75 & $\mathrm{~L}$ \\
\hline & Conversion factor biomass in TSS & $\mathrm{i}_{\mathrm{TSS}, \mathrm{BM}}$ & g TSS.g $X_{B M}^{-1}$ & $0.855 \div 0.945$ & Hauduc et al. (2010) & 0.89 & $\mathrm{C}$ \\
\hline & Anoxic yield factor for heterotrophs & $\eta_{y_{-} \mathrm{H}}$ & - & $0.5 \div 0.99$ & Hauduc et al. (2010) & 0.9 & $\mathrm{~L}$ \\
\hline & Yield of $\mathrm{X}_{\mathrm{AOB}}$ growth & $\mathrm{Y}_{\mathrm{AOB}}$ & $\begin{array}{l}\mathrm{g} \mathrm{X} \text { AOB.g } \\
\mathrm{S}_{\mathrm{NH} 4}^{-1}\end{array}$ & $0.165 \div 0.195$ & $\begin{array}{l}\text { Mannina and Cosenza } \\
\text { (2015) }\end{array}$ & 0.18 & $\mathrm{~L}$ \\
\hline & Yield of $\mathrm{X}_{\mathrm{NOB}}$ growth & $\mathrm{Y}_{\mathrm{NOB}}$ & $\begin{array}{l}\mathrm{g} \mathrm{X}_{\mathrm{NOB}} \cdot \mathrm{g} \\
\mathrm{S}_{\mathrm{NO} 2}^{-1}\end{array}$ & $0.045 \div 0.075$ & $\begin{array}{l}\text { Mannina and Cosenza } \\
\text { (2015) }\end{array}$ & 0.052 & $\mathrm{C}$ \\
\hline & Conversion factor for $\mathrm{NO}_{3}$ in $\mathrm{COD}$ & $\mathrm{i}_{\mathrm{COD} \_\mathrm{NO} 3}$ & $\begin{array}{l}\text { g COD.g } \\
\mathrm{N}^{-1}\end{array}$ & - & $\begin{array}{l}\text { Vanrolleghem et al. } \\
\text { (2005) }\end{array}$ & -4.571 & M \\
\hline & Conversion factor for $\mathrm{NO}_{2}$ in $\mathrm{COD}$ & $\mathrm{i}_{\mathrm{COD} \_\mathrm{NO} 2}$ & $\begin{array}{l}\text { g COD.g } \\
\mathrm{N}^{-1}\end{array}$ & - & $\begin{array}{l}\text { Vanrolleghem et al. } \\
\text { (2005) }\end{array}$ & -3.429 & M \\
\hline & Conversion factor for NO in COD & $\mathrm{i}_{\mathrm{COD} \_\mathrm{NO}}$ & $\begin{array}{l}\text { g COD.g } \\
\mathrm{N}^{-1}\end{array}$ & - & $\begin{array}{l}\text { Vanrolleghem et al. } \\
\text { (2005) }\end{array}$ & -2.857 & M \\
\hline & Conversion factor for $\mathrm{N}_{2} \mathrm{O}$ in $\mathrm{COD}$ & $\mathrm{i}_{\mathrm{COD} \_\mathrm{N} 2 \mathrm{O}}$ & $\begin{array}{l}\text { g COD.g } \\
\mathrm{N}^{-2}\end{array}$ & - & $\begin{array}{l}\text { Vanrolleghem et al. } \\
\text { (2005) }\end{array}$ & -2.286 & M \\
\hline & Conversion factor for $\mathrm{N}_{2}$ in $\mathrm{COD}$ & $\mathrm{i}_{\mathrm{COD} \_\mathrm{N} 2}$ & $\begin{array}{l}\text { g COD.g } \\
\mathrm{N}^{-1}\end{array}$ & - & $\begin{array}{l}\text { Vanrolleghem et al. } \\
\text { (2005) }\end{array}$ & -1.714 & M \\
\hline \multirow[t]{23}{*}{ Kinetic } & Maximum specific hydrolysis rate & $\mathrm{k}_{\mathrm{h}}$ & $\begin{array}{l}g X_{S} g \\
X_{H}^{-1} d^{-1}\end{array}$ & $1.5 \div 4.5$ & Hauduc et al. (2010) & 1.72 & $\mathrm{~L}$ \\
\hline & Half saturation parameter for $\mathrm{X}_{\mathrm{S}} / \mathrm{X}_{\mathrm{H}}$ & $\mathrm{K}_{\mathrm{X}}$ & $\mathrm{g} \mathrm{X}_{\mathrm{S}} \cdot \mathrm{g} \mathrm{X}_{\mathrm{H}}^{-1}$ & $0.03 \div 0.12$ & Hauduc et al. (2010) & 0.1 & $\mathrm{~L}$ \\
\hline & $\begin{array}{l}\text { Correction factor for hydrolysis under anoxic } \\
\text { conditions }\end{array}$ & $\eta_{\mathrm{NO}, \mathrm{HYD}}$ & - & $0.55 \div 0.65$ & Hauduc et al. (2010) & 0.65 & $\mathrm{~L}$ \\
\hline & Half saturation/inhibition parameter for $\mathrm{SO}_{2}$ & $\mathrm{~K}_{\mathrm{O} 2, \mathrm{HYD}}$ & $\mathrm{g} \mathrm{S}_{\mathrm{O} 2} \cdot \mathrm{m}^{-3}$ & $0.15 \div 0.25$ & Hauduc et al. (2010) & 0.23 & $\mathrm{C}$ \\
\hline & Half saturation/inhibition parameter for $\mathrm{S}_{\mathrm{NO} 3}$ & $\mathrm{~K}_{\mathrm{NO} 3, \mathrm{HYD}}$ & g N.m $\mathrm{m}^{-3}$ & $0.4 \div 0.6$ & Hauduc et al. (2010) & 0.44 & $\mathrm{C}$ \\
\hline & Maximum growth rate of $\mathrm{X}_{\mathrm{H}}$ & $\mu_{\mathrm{H}}$ & $\mathrm{d}^{-1}$ & $0.5 \div 5$ & $\begin{array}{l}\text { Mannina and Cosenza } \\
\text { (2015) }\end{array}$ & 0.9 & $\mathrm{C}$ \\
\hline & $\begin{array}{l}\text { Correction factor for heterotrophic anoxic growth } \\
\text { reducing } \mathrm{NO}_{3} \text { to } \mathrm{NO}_{2}\end{array}$ & $\eta_{\mathrm{g} 2}$ & - & $0.25 \div 0.35$ & $\begin{array}{l}\text { Mannina and Cosenza } \\
\text { (2015) }\end{array}$ & 0.28 & $\mathrm{~L}$ \\
\hline & $\begin{array}{l}\text { Correction factor for heterotrophic anoxic growth } \\
\text { reducing } \mathrm{NO}_{2} \text { to } \mathrm{NO}\end{array}$ & $\eta_{\mathrm{g} 3}$ & - & $0.1 \div 0.2$ & $\begin{array}{l}\text { Mannina and Cosenza } \\
\text { (2015) }\end{array}$ & 0.18 & $\mathrm{C}$ \\
\hline & $\begin{array}{l}\text { Correction factor for heterotrophic anoxic growth } \\
\text { reducing } \mathrm{NO} \text { to } \mathrm{N}_{2} \mathrm{O}\end{array}$ & $\eta_{\mathrm{g} 4}$ & - & $0.3 \div 0.4$ & $\begin{array}{l}\text { Mannina and Cosenza } \\
\text { (2015) }\end{array}$ & 0.36 & $\mathrm{C}$ \\
\hline & $\begin{array}{l}\text { Correction factor for heterotrophic anoxic growth } \\
\text { reducing } \mathrm{N}_{2} \mathrm{O} \text { to } \mathrm{N}_{2}\end{array}$ & $\eta_{\mathrm{g} 5}$ & - & $0.3 \div 0.4$ & $\begin{array}{l}\text { Mannina and Cosenza } \\
\text { (2015) }\end{array}$ & 0.35 & $\mathrm{~L}$ \\
\hline & Decay rate for $\mathrm{X}_{\mathrm{H}}$ & $\mathrm{b}_{\mathrm{H}}$ & $\mathrm{d}^{-1}$ & $0.2 \div 0.6$ & $\begin{array}{l}\text { Mannina and Cosenza } \\
\text { (2015) }\end{array}$ & 0.6 & $\mathrm{~L}$ \\
\hline & Half saturation parameter for $\mathrm{SO}_{2}$ for $\mathrm{X}_{\mathrm{H}}$ & $\mathrm{K}_{\mathrm{O} 2, \mathrm{H}}$ & $\mathrm{g} \mathrm{S}_{\mathrm{O} 2} \cdot \mathrm{m}^{-3}$ & $0.1 \div 0.5$ & Jeppsson et al. (2007) & 0.5 & $\mathrm{~L}$ \\
\hline & Half saturation parameter for $\mathrm{S}_{\mathrm{NO} 3}$ & $\mathrm{~K}_{\mathrm{NO} 3}$ & $\mathrm{~g} \mathrm{~S}_{\mathrm{NO} 3} \cdot \mathrm{m}^{-3}$ & $0.2 \div 0.7$ & $\begin{array}{l}\text { Hiatt and Grady } \\
(2008)\end{array}$ & 0.3 & $\mathrm{C}$ \\
\hline & Half saturation parameter for $\mathrm{S}_{\mathrm{NO} 2}$ & $\mathrm{~K}_{\mathrm{NO} 2}$ & $\mathrm{~g} \mathrm{~S}_{\mathrm{NO} 2} \cdot \mathrm{m}^{-3}$ & $0.18 \div 0.22$ & $\begin{array}{l}\text { Hiatt and Grady } \\
(2008)\end{array}$ & 0.21 & $\mathrm{C}$ \\
\hline & Half saturation parameter for $\mathrm{S}_{\mathrm{NO}}$ & $\mathrm{K}_{\mathrm{NO}}$ & $\mathrm{g} \mathrm{S}_{\mathrm{NO}} \cdot \mathrm{m}^{-3}$ & $0.045 \div 0.055$ & $\begin{array}{l}\text { Hiatt and Grady } \\
(2008)\end{array}$ & 0.05 & $\mathrm{~L}$ \\
\hline & Half saturation parameter for $S_{\mathrm{N} 20}$ & $\mathrm{~K}_{\mathrm{N} 2 \mathrm{O}}$ & $\mathrm{g} \mathrm{S}_{\mathrm{N} 2 \mathrm{O}} \cdot \mathrm{m}^{-3}$ & $0.045 \div 0.055$ & $\begin{array}{l}\text { Mannina and Cosenza } \\
\text { (2015) }\end{array}$ & 0.052 & $\mathrm{C}$ \\
\hline & $\mathrm{NO}$ inhibition coefficient (reducing $\mathrm{NO}_{2}$ to $\mathrm{NO}$ ) & $\mathrm{K}_{\mathrm{I} 3 \mathrm{NO}}$ & $\mathrm{g} \mathrm{S}_{\mathrm{NO}} \cdot \mathrm{m}^{-3}$ & $0.45 \div 0.55$ & $\begin{array}{l}\text { Mannina and Cosenza } \\
\text { (2015) }\end{array}$ & 0.48 & $\mathrm{C}$ \\
\hline & NO inhibition coefficient (reducing $\mathrm{NO}$ to $\mathrm{N}_{2} \mathrm{O}$ ) & $\mathrm{K}_{\mathrm{I} 4 \mathrm{NO}}$ & $\mathrm{g} \mathrm{S}_{\mathrm{NO}} \cdot \mathrm{m}^{-3}$ & $0.27 \div 0.33$ & $\begin{array}{l}\text { Mannina and Cosenza } \\
\text { (2015) }\end{array}$ & 0.3 & $\mathrm{~L}$ \\
\hline & NO inhibition coefficient (reducing $\mathrm{N}_{2} \mathrm{O}$ to $\mathrm{NO}$ ) & $\mathrm{K}_{\mathrm{I} 5 \mathrm{NO}}$ & $\mathrm{g} \mathrm{S}_{\mathrm{NO}} \cdot \mathrm{m}^{-3}$ & $0.0675 \div 0.0825$ & $\begin{array}{l}\text { Hiatt and Grady } \\
(2008)\end{array}$ & 0.075 & $\mathrm{~L}$ \\
\hline & Half saturation parameter for $\mathrm{S}_{\mathrm{NH} 4}$ for $\mathrm{X}_{\mathrm{H}}$ & $\mathrm{K}_{\mathrm{NH} 4, \mathrm{H}}$ & $\mathrm{g} \mathrm{S}_{\mathrm{NH} 4} \cdot \mathrm{m}^{-3}$ & $0.025 \div 0.1$ & $\begin{array}{l}\text { Mannina and Cosenza } \\
\text { (2015) }\end{array}$ & 0.095 & $\mathrm{~L}$ \\
\hline & Half saturation parameter for $S_{A L K}$ for $X_{H}$ & $\mathrm{~K}_{\mathrm{ALK}, \mathrm{H}}$ & $\begin{array}{l}\mathrm{mol} \mathrm{HCO}_{3}^{-} \text {. } \\
\mathrm{m}^{-3}\end{array}$ & $0.08 \div 0.12$ & $\begin{array}{l}\text { Hiatt and Grady } \\
(2008)\end{array}$ & 0.09 & $\mathrm{C}$ \\
\hline & Hydrolysis rate coefficient for $\mathrm{S}_{\mathrm{UAP}}$ & $\mathrm{k}_{h, U A P}$ & $\mathrm{~d}^{-1}$ & $\begin{array}{l}5.9310^{-7} \div 8.89 \\
10^{-7}\end{array}$ & $\begin{array}{l}\text { Mannina and Cosenza } \\
\text { (2015) }\end{array}$ & $810^{-7}$ & $\mathrm{C}$ \\
\hline & Hydrolysis rate coefficient for $S_{\mathrm{BAP}}$ & $\mathrm{k}_{h, B A P}$ & $\mathrm{~d}^{-1}$ & $0.00816 \div 0.01224$ & $\begin{array}{l}\text { Mannina and Cosenza } \\
\text { (2015) }\end{array}$ & 0.0102 & $\mathrm{~L}$ \\
\hline
\end{tabular}


Table A.1 (continued)

\begin{tabular}{|c|c|c|c|c|c|c|c|}
\hline Description & & Symbol & Unit & Range & Reference & $\begin{array}{l}\text { Value } \\
\mathrm{T}=20^{\circ} \mathrm{C}\end{array}$ & Source \\
\hline & Maximum specific growth rate of $\mathrm{X}_{\mathrm{AOB}}$ & $\mu_{\mathrm{AUT}, \mathrm{AOB}}$ & $\mathrm{d}^{-1}$ & $0.4 \div 0.7$ & $\begin{array}{l}\text { Hiatt and Grady } \\
(2008)\end{array}$ & 0.68 & C \\
\hline & Maximum specific growth rate of $\mathrm{X}_{\mathrm{NOB}}$ & $\mu_{\mathrm{AUT}, \mathrm{NOB}}$ & $\mathrm{d}^{-1}$ & $0.4 \div 0.7$ & $\begin{array}{l}\text { Hiatt and Grady } \\
\text { (2008) }\end{array}$ & 0.55 & $\mathrm{C}$ \\
\hline & Decay coefficient of $\mathrm{X}_{\mathrm{AOB}}$ & $\mathrm{b}_{\mathrm{AUT}, \mathrm{AOB}}$ & $\mathrm{d}^{-1}$ & $0.077 \div 0.115$ & $\begin{array}{l}\text { Mannina and Cosenza } \\
\text { (2015) }\end{array}$ & 0.096 & $\mathrm{~L}$ \\
\hline & Decay coefficient of $\mathrm{X}_{\mathrm{NOB}}$ & $\mathrm{b}_{\mathrm{AUT}, \mathrm{NOB}}$ & $\mathrm{d}^{-1}$ & $0.077 \div 0.115$ & $\begin{array}{l}\text { Mannina and Cosenza } \\
\text { (2015) }\end{array}$ & 0.096 & $\mathrm{~L}$ \\
\hline & Half saturation parameter for $\mathrm{S}_{\mathrm{O} 2}$ (related to $\mathrm{X}_{\mathrm{AOB}}$ ) & $\mathrm{K}_{\mathrm{O}, \mathrm{AOB}}$ & $\mathrm{g} \mathrm{S}_{\mathrm{O} 2} \cdot \mathrm{m}^{-3}$ & $0.3 \div 1$ & $\begin{array}{l}\text { Mannina and Cosenza } \\
\text { (2015) }\end{array}$ & 0.6 & $\mathrm{~L}$ \\
\hline & Half saturation parameter for $\mathrm{S}_{\mathrm{O} 2}$ (related to $\mathrm{X}_{\mathrm{NOB}}$ ) & $\mathrm{K}_{\mathrm{O}, \mathrm{NOB}}$ & $\mathrm{g} \mathrm{S}_{\mathrm{O} 2} \cdot \mathrm{m}^{-3}$ & $0.9 \div 1.3$ & $\begin{array}{l}\text { Mannina and Cosenza } \\
\text { (2015) }\end{array}$ & 1.2 & $\mathrm{~L}$ \\
\hline & Half saturation coefficient for free ammonia & $\mathrm{K}_{\mathrm{FA}}$ & $\mathrm{g} \mathrm{S}_{\mathrm{FA}} \cdot \mathrm{m}^{-3}$ & $0.00675 \div 0.00825$ & $\begin{array}{l}\text { Mannina and Cosenza } \\
\text { (2015) }\end{array}$ & 0.0071 & $\mathrm{C}$ \\
\hline & Free ammonia inhibition coefficient (related to $\mathrm{X}_{\mathrm{AOB}}$ ) & $\mathrm{K}_{\mathrm{IgFA}}$ & $\mathrm{g} \mathrm{S} \mathrm{FA}_{\mathrm{FA}} \cdot \mathrm{m}^{-3}$ & $0.9 \div 1$ & $\begin{array}{l}\text { Mannina and Cosenza } \\
\text { (2015) }\end{array}$ & 0.95 & $\mathrm{C}$ \\
\hline & Free ammonia inhibition coefficient (related to $\mathrm{X}_{\mathrm{NOB}}$ ) & $\mathrm{K}_{\mathrm{I} 10 \mathrm{FA}}$ & $\mathrm{g} \mathrm{S}_{\mathrm{FA}} \cdot \mathrm{m}^{-3}$ & $0.18 \div 0.22$ & $\begin{array}{l}\text { Mannina and Cosenza } \\
\text { (2015) }\end{array}$ & 0.21 & $\mathrm{C}$ \\
\hline & Half saturation coefficient for free nitrous acid & $\mathrm{K}_{\mathrm{FNA}}$ & $\mathrm{g} \mathrm{S}_{\mathrm{FNA}} \cdot \mathrm{m}^{-3}$ & $0.00009 \div 0.00011$ & $\begin{array}{l}\text { Mannina and Cosenza } \\
\text { (2015) }\end{array}$ & 0.000099 & $\mathrm{C}$ \\
\hline & Free nitrous acid inhibition coefficient (related to $\mathrm{X}_{\mathrm{AOB}}$ ) & $\mathrm{K}_{\mathrm{IOFNA}}$ & $\mathrm{g} \mathrm{S}_{\mathrm{FNA}} \cdot \mathrm{m}^{-3}$ & $0.09 \div 0.11$ & $\begin{array}{l}\text { Mannina and Cosenza } \\
\text { (2015) }\end{array}$ & 0.1 & $\mathrm{~L}$ \\
\hline & Free nitrous acid inhibition coefficient (related to $\mathrm{X}_{\mathrm{NOB}}$ ) & $\mathrm{K}_{\mathrm{I} 10 \mathrm{FNA}}$ & $\mathrm{g} \mathrm{S}_{\mathrm{FNA}} \cdot \mathrm{m}^{-3}$ & $0.036 \div 0.044$ & $\begin{array}{l}\text { Mannina and Cosenza } \\
\text { (2015) }\end{array}$ & 0.038 & $\mathrm{C}$ \\
\hline & Half saturation parameter for $\mathrm{S}_{\mathrm{ALK}}$ for $\mathrm{X}_{\mathrm{AUT}}$ & $\mathrm{K}_{\mathrm{ALK}, \mathrm{AUT}}$ & $\mathrm{mol} \mathrm{HCO}_{3}^{-}$ & $0.4 \div 0.6$ & $\begin{array}{l}\text { Mannina and Cosenza } \\
(2015)\end{array}$ & 0.5 & $\mathrm{~L}$ \\
\hline & $\begin{array}{l}\text { Oxygen transfer coefficient for aerobic tank to evaluate } \\
\text { the overall } \mathrm{k}_{\mathrm{LaT}}\end{array}$ & $\mathrm{k}_{1,2}$ & $\mathrm{~d}^{-1}$ & $240 \div 360$ & Jeppsson et al. (2007) & 300 & $\mathrm{~L}$ \\
\hline & $\begin{array}{l}\text { Oxygen transfer coefficient for aerobic tank to evaluate } \\
\text { the overall } \mathrm{k}_{\mathrm{LaT}}\end{array}$ & $\mathrm{k}_{2,2}$ & $\mathrm{~d} \mathrm{~m}^{-3}$ & $-1.82 \div-1$ & Jeppsson et al. (2007) & -0.42 & $\mathrm{C}$ \\
\hline & $\begin{array}{l}\text { Oxygen transfer coefficient for MBR tank to evaluate } \\
\text { the overall } \mathrm{k}_{\mathrm{LaT}}\end{array}$ & $\mathrm{k}_{1,3}$ & $\mathrm{~d}^{-1}$ & $80 \div 120$ & Jeppsson et al. (2007) & 90 & $\mathrm{~L}$ \\
\hline & $\begin{array}{l}\text { Oxygen transfer coefficient for MBR tank to evaluate } \\
\text { the overall } \mathrm{k}_{\mathrm{LaT}}\end{array}$ & $\mathrm{k}_{2,3}$ & $\mathrm{~d} \mathrm{~m}^{-3}$ & $-1.82 \div-1$ & Jeppsson et al. (2007) & -0.55 & $\mathrm{C}$ \\
\hline & Overall $\mathrm{k}_{\mathrm{LaT}}$ for $\mathrm{N}_{2} \mathrm{O}$ & $\mathrm{k}_{\mathrm{LaT} \_} \mathrm{N}_{2} \mathrm{O}$ & $\mathrm{d}^{-1}$ & 108 & $\begin{array}{l}\text { Mampaey et al. } \\
\text { (2015) }\end{array}$ & 108 & $\mathrm{~L}$ \\
\hline & Overall $\mathrm{k}_{\mathrm{LaT}}$ for $\mathrm{CO}_{2}$ & $\mathrm{k}_{\mathrm{LaT}-\mathrm{CO}_{2}}$ & & 97 & $\begin{array}{l}\text { Mampaey et al. } \\
(2015)\end{array}$ & 87 & $\mathrm{~L}$ \\
\hline & Salinity inhibition factor for heterotrophs & $\mathrm{I}_{\mathrm{S}, \mathrm{H}}$ & $\mathrm{d}^{-1}$ & $0.24 \div 0.36$ & $\begin{array}{l}\text { Park and Marchand } \\
\text { (2005) }\end{array}$ & 0.288 & $\mathrm{C}$ \\
\hline & Salinity inhibition factor for autotrophs & $\mathrm{I}_{\mathrm{S}, \mathrm{A}}$ & $\mathrm{d}^{-1}$ & $0.24 \div 0.6$ & $\begin{array}{l}\text { Park and Marchand } \\
(2005)\end{array}$ & 0.48 & $\mathrm{~L}$ \\
\hline \multirow[t]{6}{*}{ Physical } & Erosion rate coefficient of the dynamic sludge & $\beta$ & - & $0.00001 \div 0.001$ & $\begin{array}{l}\text { Mannina et al. } \\
\text { (2011b) }\end{array}$ & 0.0138 & $\mathrm{~L}$ \\
\hline & Stickiness of the biomass particles & $\alpha$ & - & $0 \div 1$ & $\begin{array}{l}\text { Mannina et al. } \\
\text { (2011b) }\end{array}$ & 0.32 & $\mathrm{C}$ \\
\hline & Compressibility of cake & $\gamma$ & $\mathrm{Kg} \mathrm{m}^{-3} \mathrm{~s}$ & $\begin{array}{l}1.7510^{-5} \div 3,25 \\
10^{-5}\end{array}$ & $\begin{array}{l}\text { Mannina et al. } \\
\text { (2011b) }\end{array}$ & $1.7510^{-5}$ & $\mathrm{~L}$ \\
\hline & Substrate fraction below the critical molecular weight & $\mathrm{f}$ & - & $0.001 \div 0.99$ & $\begin{array}{l}\text { Mannina et al. } \\
\text { (2011b) }\end{array}$ & 0.86 & $\mathrm{C}$ \\
\hline & Screening parameter & $\lambda$ & $\mathrm{m}^{-1}$ & $1000 \div 2000$ & $\begin{array}{l}\text { Mannina et al. } \\
\text { (2011b) }\end{array}$ & 1487 & $\mathrm{C}$ \\
\hline & Efficiency of backwashing & $C_{E}$ & - & $0.986 \div 0.999$ & $\begin{array}{l}\text { Mannina et al. } \\
\text { (2011b) }\end{array}$ & $9.86 \mathrm{E}-01$ & $\mathrm{C}$ \\
\hline \multirow[t]{5}{*}{ Fractionation } & Fraction of influent $S_{s}$ & $\mathrm{~F}_{\mathrm{Ss}}$ & - & $0.1 \div 0.3$ & $\begin{array}{l}\text { Mannina and Cosenza } \\
\text { (2015) }\end{array}$ & 0.3 & $\mathrm{~L}$ \\
\hline & Fraction of influent $S_{I}$ & $\mathrm{~F}_{\mathrm{SI}}$ & - & $0.114 \div 0.126$ & $\begin{array}{l}\text { Mannina and Cosenza } \\
\text { (2015) }\end{array}$ & 0.12 & $\mathrm{~L}$ \\
\hline & Fraction of influent $\mathrm{X}_{\mathrm{I}}$ & $\mathrm{F}_{\mathrm{XI}}$ & - & $0.05 \div 0.15$ & $\begin{array}{l}\text { Mannina and Cosenza } \\
\text { (2015) }\end{array}$ & 0.12 & C \\
\hline & Fraction of influent $\mathrm{X}_{\mathrm{H}}$ & $\mathrm{F}_{\mathrm{XH}}$ & - & $0.06 \div 0.18$ & $\begin{array}{l}\text { Mannina and Cosenza } \\
\text { (2015) }\end{array}$ & 0.1 & $\mathrm{~L}$ \\
\hline & Fraction of influent $\mathrm{X}_{\mathrm{S}}$ & $\mathrm{F}_{\mathrm{XS}}$ & - & $0.244 \div 0.676$ & $\begin{array}{l}\text { Mannina and Cosenza } \\
\text { (2015) }\end{array}$ & 0.36 & C \\
\hline
\end{tabular}

to salt inhibition. This result is of particular interest to $\mathrm{N}_{2} \mathrm{O}$ modelling, because salinity has been identified as one of the most influencing factors for the $\mathrm{N}_{2} \mathrm{O}$ emission during nitrification (Kampschreur et al., 2009). In terms of heterotrophic biomass the value of $\mu_{\mathrm{H}}$ obtained $\left(0.9 \mathrm{~d}^{-1}\right)$ is lower than literature rates (Jiang et al., 2008; Mannina and Cosenza, 2015). Such low value is likely due to the high sludge retention time (SRT); indeed, the pilot plant was operated at indefinite SRT value. Such an operational condition could lead to the accumulation of inert biomass and to the slowly biomass growth (Judd and Judd, 2010).

Regarding the physical model factors they have some differences with respect to the literature. For example the value of the backwashing efficiency coefficient $\left(\mathrm{C}_{\mathrm{E}}\right)$ resulted lower than previous literature; the value obtained here is equal to 0.986 while in 
Table A.2

Gujer Matrix of the SB-MBR biological sub-model; in grey the new processes added with respect to ASM1.

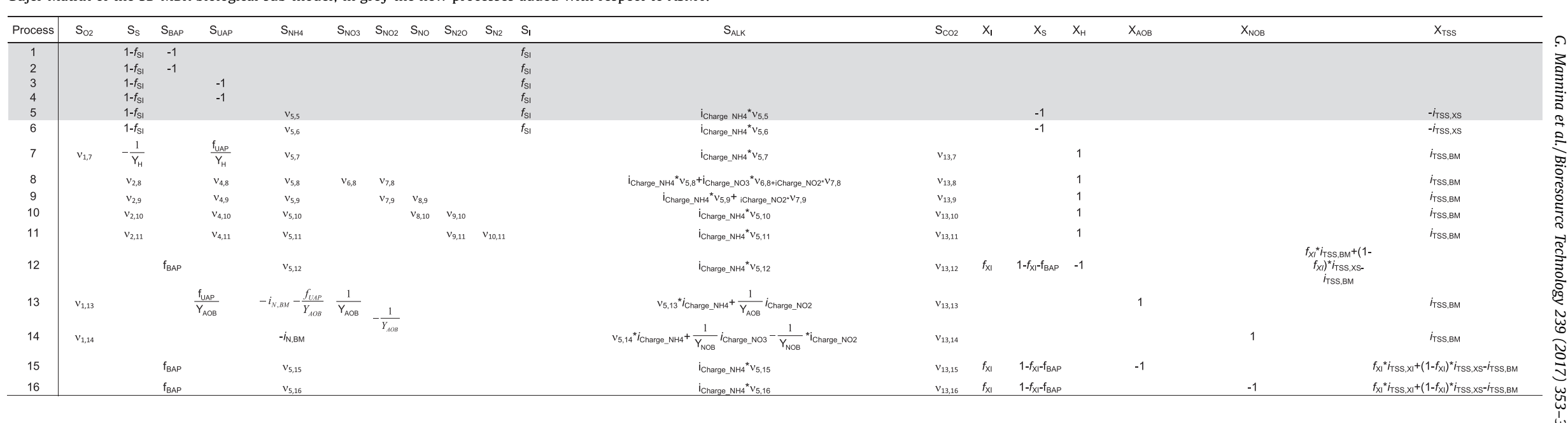

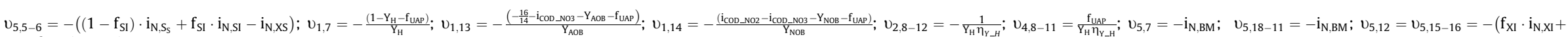
$\left.\left(1-\mathrm{f}_{\mathrm{XI}}\right) \cdot \mathrm{i}_{\mathrm{N} . \mathrm{XS}}-\mathrm{i}_{\mathrm{N} . \mathrm{BM}}\right)$

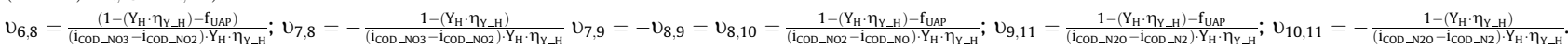


Table A.3

Process rate equations of the biological sub-model; in grey the rate related to the new hydrolysis processes.

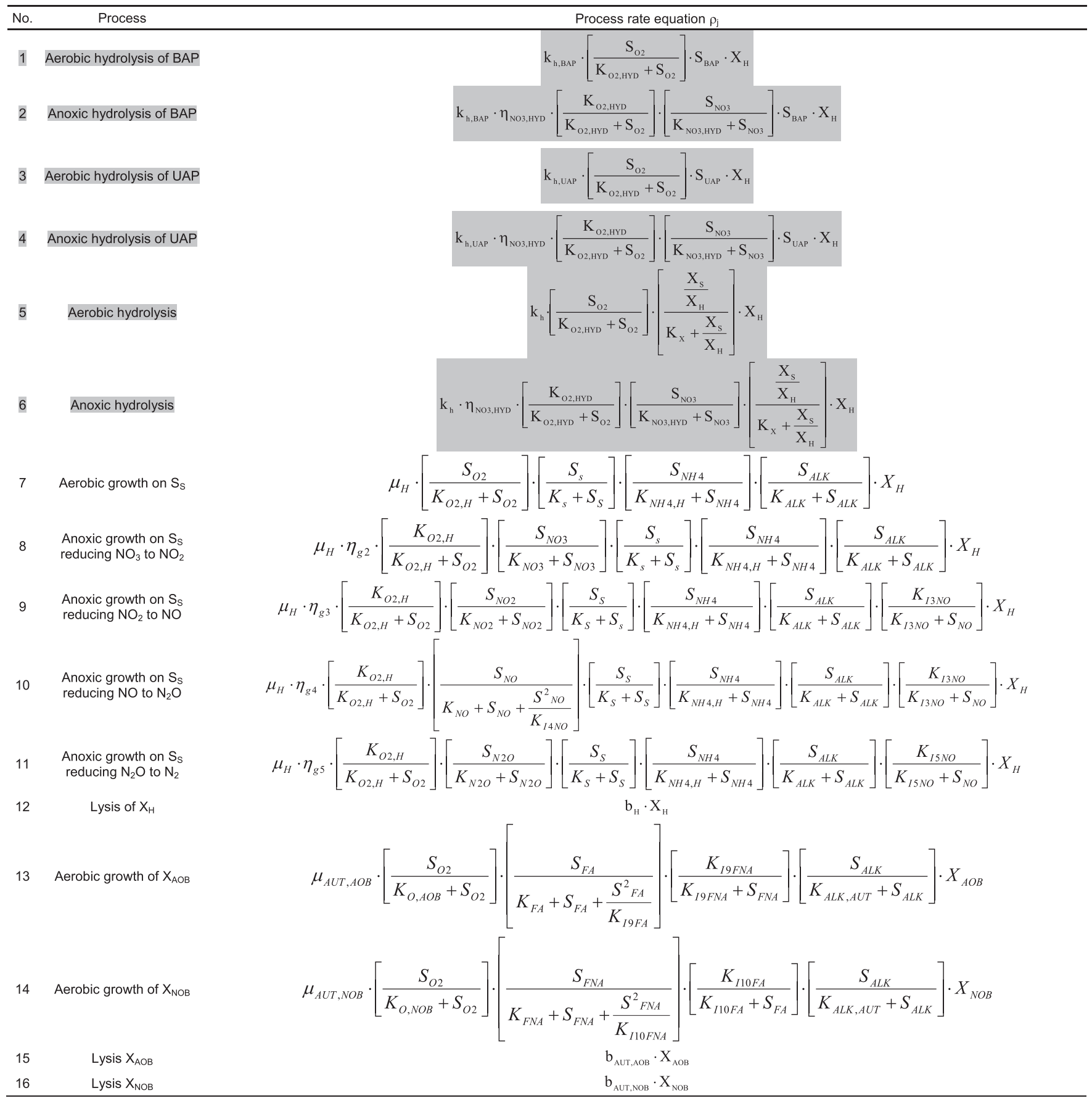

previous studies the value of 0.996 (Mannina and Cosenza, 2013, 2015) was obtained. This lower value for $C_{E}$ suggests a potential increase of the membrane resistance caused by the cake layer, likely due to the mixed liquor features. Furthermore, the screening parameter $(\lambda)$ has here a value of $1487 \mathrm{~m}^{-1}$ against the value of $1520.29 \mathrm{~m}^{-1}$ of previous studies (Mannina and Cosenza, 2013, 2015). Such result suggested that the different features of biomass due to the presence of salinity also influence the membrane fouling. Indeed, the factors related to the SMP still have different value if compared with literature. In particular, the fraction of $\mathrm{S}_{\mathrm{UAP}}$ due to the biomass decay $\left(f_{\mathrm{UAP}}\right)$ obtained here was higher compared with that observed in literature (Jiang et al., 2008) likely due to the stress effect on the heterotrophic biomass grow due to the salinity and to the high SRT. Furthermore, the worsening of membrane fouling can be also due to the increase of the mixed liquor viscosity and to the reduction of the oxygen solubility with the increasing of the salinity (Lay et al., 2010).

For sake of completeness in Fig. 4 the calibrated and measured pattern for $\mathrm{COD}_{\mathrm{TOT}, 1}(\mathrm{a}), \mathrm{S}_{\mathrm{NO} 3,1}$ (b), $\mathrm{COD}_{\mathrm{sol}, 2}(\mathrm{c}), \mathrm{R}_{\mathrm{T}}(\mathrm{d}), \mathrm{S}_{\mathrm{N} 2 \mathrm{O}, 2}$ (e) and $\mathrm{S}_{\mathrm{GHG}, \mathrm{N} 2 \mathrm{O}, 2}(\mathrm{f})$ are reported. Despite the salinity increase, a good prediction of COD model outputs occurred (Fig. 4a and c). Such result has peculiar interest because since these model outputs $\left(\mathrm{COD}_{\mathrm{TOT}, 1}\right.$ of Fig. $4 \mathrm{a}$ and $\mathrm{COD}_{\mathrm{sol}, 2}$ of $4 \mathrm{c}$ ) are the sum of different model outputs. Further, from the results of Fig. $4 \mathrm{~d}$ one can observe that the model allows to describe the increase of $\mathrm{R}_{\mathrm{T}}$ occurred with the increase of salinity. 
However, during Phase VI (specifically between days 62 and 78) occurred some technical problems, not implemented in the model algorithms. When the technical problems were resolved, the model was again able to reproduce the measured $R_{T}$ values. In terms of $\mathrm{N}_{2} \mathrm{O}$, the model shows an acceptable adaption between simulated values and measured values (data reported for each replicate) (Fig. 5a and b). Specifically, the increase of $\mathrm{N}_{2} \mathrm{O}$ emission from aerobic tank with the salinity is reproduced by the model. Details on the model efficiency will be provided below.

Table 2 summarizes the results related to the model efficiencies. By analysing data of Table 2 one can observe that acceptable efficiencies were obtained for the model outputs of Sections 1,2 and 4 (namely, anoxic, aerobic and MBR, respectively). More precisely, the average efficiency of the model outputs of the anoxic tank (Section 1 ) was equal to 0.42 . For the model output of the aerobic tank (Section 2) the average efficiency was equal to 0.41 . While, 0.33 for the model outputs of the MBR (Section 4). Conversely, the lowest efficiency value was obtained for the model outputs of the Section 3 ( 0.28 on average). Such a result is mainly debited to the lower number of measured data for the Section 3 with respect to the other sections. Regarding the total resistance $\left(\mathrm{R}_{\mathrm{T}}\right)$, the model provided a quite high efficiency value $(0.79)$ (Table 2$)$. This result suggests a good model ability to reproduce membrane fouling mechanisms.

\subsection{Uncertainty analysis}

Fig. 6 shows the uncertainty analysis results for $\operatorname{COD}_{\text {TOT,1 }}$ (a), $\mathrm{S}_{\mathrm{NO}, 1}$ (b), $\mathrm{S}_{\mathrm{NO}, 3}$ (c), $\mathrm{R}_{\mathrm{T}}(\mathrm{d}), \mathrm{S}_{\mathrm{GHG}, \mathrm{N} 2 \mathrm{O}, 1}$ (e), $\mathrm{S}_{\mathrm{N} 2 \mathrm{O}, 1}$ (f), $\mathrm{S}_{\mathrm{GHG}, \mathrm{N} 2 \mathrm{O}, 2}$ (g) and $\mathrm{S}_{\mathrm{N} 2 \mathrm{O}, 2}(\mathrm{~h})$.

By analysing the data reported in Fig. 6 one can observe that the uncertainty band widths (quantified as average difference between $95 \%$ and $5 \%$ uncertainty band value) changes with the model outputs through the different plant sections (e.g., greater for $\mathrm{COD}_{\mathrm{TOT}, 1}$ ) (Fig. 6a). This is due to the different role that the key processes occurring inside each plant section have on the model outputs variation and on the interlinkage among model outputs. Indeed,

\section{Table A.4}

Key processes taken into account in the physical sub-model.

\begin{tabular}{|c|c|}
\hline Description & Equations \\
\hline Drag force & $\mathrm{F}_{\mathrm{a}}=3 \pi \mu_{\mathrm{s}} \mathrm{d}_{\mathrm{p}} \mathrm{J}$ \\
\hline Lifting force & $\mathrm{F}_{1}=\mathrm{C}_{\mathrm{d}} \mathrm{d}_{\mathrm{p}} \mu_{\mathrm{s}} \mathrm{G} \frac{\pi \mathrm{d}_{\mathrm{p}}^{2}}{8}$ \\
\hline $\begin{array}{l}\text { Probability of particle } \\
\text { deposition on } \\
\text { membrane surface }\end{array}$ & $E=\frac{F_{a}}{F_{1}+F_{a}}=\frac{24 J}{24 J+C_{d} d_{p} G}$ \\
\hline $\begin{array}{l}\text { Rate of biomass } \\
\text { attachment }\end{array}$ & $\left(\frac{\mathrm{dM}_{\mathrm{dc}}}{\mathrm{dt}}\right)_{\mathrm{a}}=E C_{\mathrm{SS}} J=\frac{24 \mathrm{C}_{\mathrm{SS}} \mathrm{J}^{2}}{24 \mathrm{~J}+\mathrm{C}_{\mathrm{d}} \mathrm{d}_{\mathrm{p}} \mathrm{G}}$ \\
\hline Rate of sludge detachment & $\left(\frac{\mathrm{dM}_{\mathrm{dc}}}{\mathrm{dt}}\right)_{\mathrm{d}}=-\frac{\beta(1-\alpha) \mathrm{GM}_{\mathrm{dc}}^{2}}{\gamma V_{\mathrm{f}} \mathrm{t}+\mathrm{M}_{\mathrm{dc}}}$ \\
\hline Net cake deposition & $\frac{\mathrm{dM}_{\mathrm{sc}}}{\mathrm{dt}}=\frac{24 \mathrm{C}_{\mathrm{ss}} \mathrm{J}^{2}}{24 \mathrm{~J}+\mathrm{C}_{\mathrm{d}} \mathrm{d}_{\mathrm{p}} \mathrm{G}}-\frac{\beta(1-\alpha) \mathrm{GM}_{\mathrm{dc}}^{2}}{\gamma V_{\mathrm{f}} \mathrm{t}+\mathrm{M}_{\mathrm{dc}}}$ \\
\hline $\begin{array}{l}\text { Detachment rate during } \\
\text { backwashing }\end{array}$ & $\frac{\mathrm{dM}_{\mathrm{sc}}}{\mathrm{dt}}=-\eta_{\mathrm{c}} \mathrm{M}_{\mathrm{sc}}$ \\
\hline Deep-bed filtration & $\mathrm{C}_{\mathrm{sm}}=\mathrm{C}_{\mathrm{S}} \mathrm{e}(-\lambda \delta)$ \\
\hline ith total resistance & $\mathrm{R}_{\mathrm{tS}, \mathrm{i}}=\mathrm{R}_{\mathrm{m}}+\mathrm{R}_{\mathrm{p}, \mathrm{i}}+\mathrm{R}_{\mathrm{c}, \mathrm{i}}=\mathrm{R}_{\mathrm{m}}+\mathrm{R}_{\mathrm{p}, \mathrm{i}}+\left(\mathrm{R}_{\mathrm{dc}, \mathrm{i}}+\mathrm{R}_{\mathrm{sc}, \mathrm{i}}\right)$ \\
\hline Total resistance & $\mathrm{R}_{\mathrm{t}}=\sum_{\mathrm{i}=1}^{\mathrm{N}} \mathrm{R}_{\mathrm{tS}, \mathrm{i}}$ \\
\hline Trans-membrane pressure & $\mathrm{TMP}=\mu J \mathrm{R}_{\mathrm{t}}$ \\
\hline
\end{tabular}

where $\mu_{s}=$ sludge viscosity; $d_{p}=$ particle diameter; $J=$ permeate flux; $C_{d}=$ lifting force coefficient; $C_{s s}=$ suspended solid concentration of biomass sludge; $\gamma=$ compression coefficient for dynamic sludge layer; $V_{f}=$ volume of permeate produced; $\beta=$ erosion rate coefficient of dynamic sludge film; $\alpha=$ stickiness of biomass; $\eta_{\mathrm{c}}=$ efficiency of backwashing; $\mathrm{C}_{\mathrm{sm}}=$ concentration of COD at the physical membrane surface: $C_{S}=$ concentration of $C O D$ in the mixed liquor at the physical membrane surface; $R_{t S, i}=$ total resistance of fouling in the section $\mathrm{i}, ; \mathrm{R}_{\mathrm{m}}=$ intrinsic resistance of the membrane; $R_{p, i}=$ the pore fouling resistance caused by solute deposition inside the membrane pores in the section $\mathrm{i} ; \mathrm{R}_{\mathrm{C}, \mathrm{i}}=$ resistance of cake layer in the section $i ; R_{d c, i}=$ resistance of dynamic sludge film in the section $i$; $R_{s c, i}=$ resistance of stable sludge cake in the section $i ; R_{t}=$ total fouling resistances. for example the variation of the total COD involves the combination of the variation of different state variables of the model: $X_{S}$, $\mathrm{X}_{\mathrm{i}}, \mathrm{X}_{\mathrm{H}}, \mathrm{X}_{\mathrm{AOB}}, \mathrm{X}_{\mathrm{NOB}}$. Similarly, the variation of supernatant COD involves the variation of $S_{B A P}, S_{U A P}, S_{I}, S_{S}$. A larger band width

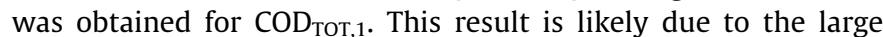
number of model factors, important for COD, varied during the uncertainty analysis. Regarding $\mathrm{R}_{\mathrm{T}}$, a very narrow band width was obtained (Fig. 6d); this result demonstrates the high accuracy of the model in reproducing the membrane fouling. Globally, $90 \%$ of measured data for the model output shown in Fig. 6 lies inside the uncertainty band.

The uncertainty band width (as average difference between $95 \%$ and $5 \%$ percentile) of the model outputs related to GHG changes with the model outputs in the different plant sections (e.g., greater for $\mathrm{S}_{\mathrm{GHG}, \mathrm{N} 2 \mathrm{O}, 1}$ and $\mathrm{S}_{\mathrm{N} 2 \mathrm{O}, 2}$ ) (Fig. 6e-h). Indeed, variation of some factors could make more uncertain the $\mathrm{N}_{2} \mathrm{O}$ production in a certain section due to the overlapping effects among different processes. For example, the increase of $k_{2,2}$ and $k_{2,3}$ could favour aerobic conditions inside the anoxic tank due to the recycled oxygen mass. Therefore, $\mathrm{N}_{2} \mathrm{O}$ formation due to the heterotrophic and autotrophic pathways could occur inside the anoxic tank.

By analysing data of Fig. 6e-h it is possible to observe that for the GHG model outputs for which a greater number of measured data was available $\left(\mathrm{S}_{\mathrm{GHG}, \mathrm{N} 2 \mathrm{O}, 1}\right.$ and $\left.\mathrm{S}_{\mathrm{GHG}, \mathrm{N} 2 \mathrm{O}, 2}\right)$ a more accurate prediction was obtained. Indeed, for $\mathrm{S}_{\mathrm{GHG}, \mathrm{N} 2 \mathrm{O}, 1}$ and $\mathrm{S}_{\mathrm{GHG}, \mathrm{N} 2 \mathrm{O}, 2}$ only the $7 \%$ and the $12 \%$ of the measured data lie outside the band width. This result is important, suggesting that long extensive databases are required to set up accurate models and reduce model uncertainty. Indeed, $60 \%$ and $46 \%$ of the measured data lie outside the band width for $\mathrm{S}_{\mathrm{N} 2 \mathrm{O}, 1}$ and $\mathrm{S}_{\mathrm{N} 2 \mathrm{O}, 2}$, respectively.

More precisely, the measured data lower than $0.01 \mathrm{mgN} \mathrm{L}^{-1}$ and $0.025 \mathrm{mgN} \mathrm{L}^{-1}$ lie outside the band for $\mathrm{S}_{\mathrm{N} 2 \mathrm{O}, 1}$ and $\mathrm{S}_{\mathrm{N} 2 \mathrm{O}, 2}$, respectively.

\section{Conclusions}

A new integrated MBR mathematical model was presented. The main contribution of the model is to consider (1) GHG emissions, (2) the influence of salinity on the process rate, (3) the SMP formation/degradation processes. The model has been calibrated by employing an innovative protocol and using an extensive data set. Results derived by the model application have improved the knowledge on $\mathrm{N}_{2} \mathrm{O}$ emissions from MBRs; for example, model factors that require to be measured for improving $\mathrm{N}_{2} \mathrm{O}$ predictions have been selected (half saturation coefficients related to the nitrogen processes or factors related to the oxygen transfer). Further future investigations could demonstrate the predictive capability of the integrated model presented here for simulating systems/conditions different to those in the calibrating data set.

\section{Acknowledgements}

This work forms part of a research project supported by grant of the Italian Ministry of Education, University and Research (MIUR) through the Research project of national interest PRIN2012 (D.M. 28 dicembre 2012 n. 957/Ric - Prot. 2012PTZAMC) entitled "Energy consumption and GreenHouse Gas (GHG) emissions in the wastewater treatment plants: a decision support system for planning and management - http://ghgfromwwtp.unipa.it" in which the first author is the Principal Investigator.

\section{Appendix A}

See Table A1 - Table A4. 


\section{References}

Bertrand-Krajewski, J.L., Barraud, S., Bardin, J.P., 2002. Uncertainties, performance indicators and decision aid applied to storm water facilities. Urban Water J. 4, 163-179.

Beven, K.J., Binley, A., 1992. The future of distributed models: model calibration and uncertainty prediction. Hydrol. Processes 6 (3), 279-298.

Corominas, L., Flores-Alsina, X., Snip, L., Vanrolleghem, P.A., 2012. Comparison of different modeling approaches to better evaluate greenhouse gas emissions from whole wastewater treatment plants. Biotechnol. Bioeng. 109, 2854-2863.

Cosenza, A., Mannina, G., Vanrolleghem, P.A., Neumann, M.B., 2013. Global sensitivity analysis in wastewater applications: a comprehensive comparison of different methods. Environ. Modell. Software 49, 40-52.

Dotto, C.B.S., Mannina, G., Kleidorfer, M., Vezzaro, L., Henrichs, M., McCarthy, D.T., Freni, G., Rauch, W., Deletic, A., 2012. Comparison of different uncertainty techniques in urban stormwater quantity and quality modelling. Water Res. 46, $2545-2558$.

Hauduc, H., Rieger, L., Ohtsuki, T., Shaw, A., Takàcs, I., Winkler, S., Héduit, A., Vanrolleghem, P.A., Gillot, S., 2011. Activated sludge modelling: development and potential use of a practical applications database. Water Sci. Technol. 63 (10), 2164-2182.

Hauduc, H., Rieger, L., Takács, I., Héduit, A., Vanrolleghem, P.A., Gillot, S., 2010. A systematic approach for model verification: application on seven published activated sludge models. Water Sci. Technol. 61, 825-839.

Henze, M., Gujer, W., Mino, T., Van Loosdrecht, M., 2000. Activated sludge models ASM1, ASM2, ASM2d and ASM3. In: IWA Task Group on Mathematical Modelling for Design and Operation of Biological Wastewater Treatment. IWA Publishing, London, UK.

Hiatt, W.C., Grady Jr., C.P.L., 2008. An updated process model for carbon oxidation, nitrification, and denitrification. Water Environ. Res. 80, 2145-2156.

IPCC, Climate Change, 2013. The Physical Science Basis. In: Contribution of Working Group I to the Fifth Assessment Report of the Intergovernmental Panel on Climate Change. Cambridge University Press, Cambridge, United Kingdom and New York, NY, USA, p. 1535.

Jeppsson, U., Pons, M.N., Nopens, I., Alex, J., Copp, J.B., Gernaey, K.V., Rosen, C. Steyer, J.P., Vanrolleghem, P.A., 2007. Benchmark simulation model no2: general protocol and exploratory case studies. Water Sci. Technol. 56 (8), 67-78.

Jiang, T., Myngheer, S., De Pauw, D.J.W., Spanjers, H., Nopens, I., Kennedy, M.D. Kennedy, M.D., Amy, G., Vanrolleghem, P.A., 2008. Modelling the production and degradation of soluble microbial products (SMP) in membrane bioreactors (MBR). Water Res. 42 (20), 4955-4964.

Johir, M.A.H., Vigneswaran, S., Kandasamy, J., BenAim, R., Grasmick, A., 2013. Effect of salt concentration on membrane bioreactor (MBR) performances: detailed organic characterization. Desalination 322, 13-20.

Judd, S.J., Judd, C., 2010. Principles and Applications of Membrane Bioreactors in Water and Wastewater Treatment. Elsevier, London, UK.

Kampschreur, M.J., Temmink, H., Kleerebezem, R., Jetten, M.S.M., Van Loosdrecht, M., 2009. Nitrous oxide emission during wastewater treatment. Water Res. 43, 4093-4103.

Lay, W.C.L., Liu, Y., Fane, A.G., 2010. Impacts of salinity on the performance of high retention membrane bioreactors for water reclamation: a review. Water Res. $44,21-40$.

Li, X., Wang, X., 2006. Modelling of membrane fouling in a submerged membrane bioreactor. J. Membr. Sci. 278, 151-161.

Luo, W., Hai, F.I., Kang, J., Price, W.E., Guo, W., Ngo, H.H., Yamamoto, K., Nghiem, L.D. 2015. Effects of salinity build-up on biomass characteristics and trace organic chemical removal: implications on the development of high retention membrane bioreactors. Bioresour. Technol. 177, 274-281.
Mampaey, K.E., van Dongen, U.G.J.M., van Loosdrecht, M.C.M., Volcke, E.I.P., 2015. Novel method for online monitoring of dissolved $\mathrm{N}_{2} \mathrm{O}$ concentrations through a gas stripping device. Environ. Technol. 36 (13), 1680-1690.

Mannina, G..Di., Bella, G., Viviani, G., 2011a. An integrated model for biological and physical process simulation in membrane bioreactors (MBR). J. Membr. Sci. 376 (1-2), 56-69.

Mannina, G., Cosenza, A., Vanrolleghem, P.A., Viviani, G., 2011b. A practical protocol for calibration of nutrient removal wastewater treatment models. J. Hydroinf. 13 (4), 575-595.

Mannina, G., Cosenza, A., 2013. The fouling phenomenon in membrane bioreactors: assessment of different strategies for energy saving. J. Membr. Sci. 444, 332 344.

Mannina, G., Cosenza, A., 2015. Quantifying sensitivity and uncertainty analysis of a new mathematical model for the evaluation of greenhouse gas emissions from membrane bioreactors. J. Membr. Sci. 475, 80-90.

Mannina, G., Ekama, G., Caniani, D., Cosenza, A., Esposito, G., Gori, R., GarridoBaserba, M., Rosso, D., Olsson, G., 2016a. Greenhouse gases from wastewater treatment - a review of modelling tools. Sci. Total Environ. 551-552, 254-270.

Mannina, G. Capodici, M., Cosenza, A., Di Trapani, D., Viviani, G., 2016b. Sequential batch membrane bioreactor for wastewater treatment: effect of salinity increase. Bioresour. Technol. 209, 205-212.

Ni, B.-J., Yuan, Z., 2015. Recent advances in mathematical modeling of nitrous oxides emissions from wastewater treatment processes. Water Res. 87, 336346.

Ni, B.-J., Yuan, Z., Chandran, K., Vanrolleghem, P.A., Murthy, S., 2013. Evaluating four mathematical models for nitrous oxide production by autotrophic ammonia oxidizing bacteria. Biotechnol. Bioeng. 110, 153-163.

Park, C., Marchland, E.A., 2006. Modelling salinity inhibition effects during biodegradation of perchlorate. J. Appl. Microbiol. 101, 222-233.

Peng, L., Ni, B.-J., Ye, L., Yuan, Z., 2015. The combined effect of dissolved oxygen and nitrite on $\mathrm{N}_{2} \mathrm{O}$ production by ammonia oxidizing bacteria in an enriched nitrifying sludge. Water Res. 73C, 29-36.

Pocquet, M., Wu, Z., Queinnec, I., Spérandio, M., 2016. A two pathway model for $\mathrm{N}_{2} \mathrm{O}$ emissions by ammonium oxidizing bacteria supported by the $\mathrm{NO} / \mathrm{N}_{2} \mathrm{O}$ variation. Water Res. 88, 948-959.

Sabba, F., Picioreanu, C., Boltz, J.P., Nerenberg, R., 2016. Predicting $\mathrm{N}_{2} \mathrm{O}$ emissions from nitrifying and denitrifying biofilms: a modeling study. Water Sci. Technol. 74 (8). http://dx.doi.org/10.2166/wst.2016.484.

Saltelli, A., Tarantola, S., Campolongo, F., Ratto, M., 2004. Sensitivity Analysis in Practice. A guide to Assessing Scientific models, Probability and Statistics Series. John Wiley \& Sons Publishers, Chichester, England.

Spérandio, M., Pocquet, M., Guo, L., Ni, B.-J., Vanrolleghem, P.A., Yuan, Z., 2016. Evaluation of different nitrous oxide production models with four continuous long-term wastewater treatment process data series. Bioprocess. Biosyst. Eng. 39 (3), 493-510.

Sweetapple, C., Fu, G., Butler, D., 2013. Identifying key sources of uncertainty in the modelling of greenhouse gas emissions from wastewater treatment. Water Res. 47, 4652-4665.

Vanrolleghem, P.A., Mannina, G., Cosenza, A., Neumann, M.B., 2015. Global sensitivity analysis for urban water quality modelling: Terminology, convergence and comparison of different methods. J. Hydrol. 522, 339-352.

Vanrolleghem, P.A., Rosen, C., Zaher, U., Copp, J., Benedetti, L., Ayesa, E., Jeppsson, U., 2005. Continuity-based interfacing of models for wastewater systems described by Petersen matrices. Water Sci. Technol. 52, 493-500.

Zhao, W., Wang, Y., Lin, X., Zhou, D., Pan, M., Yang, J., 2014. Identification of the salinity effect on $\mathrm{N}_{2} \mathrm{O}$ production pathway during nitrification: Using stepwise inhibition and 15N isotope labeling methods. Chem. Eng. J. 253, 418-426. 